\title{
Host Immune Evasion by Lyme and Relapsing Fever Borreliae: Findings to Lead Future Studies for Borrelia miyamotoi
}

OPEN ACCESS

Edited by: Monica E. Embers, Tulane University, USA

Reviewed by: Peter Kraiczy, Goethe University Frankfurt, Germany Robert D. Gilmore, Centers for Disease Control and Prevention, USA

*Correspondence:

Catherine A. Brissette catherine.brissette@med.und.edu

Specialty section: This article was submitted to Microbial Immunology, a section of the journal

Frontiers in Immunology

Received: 21 October 2016 Accepted: 05 January 2017

Published: 19 January 2017

Citation: Stone BL and Brissette CA (2017) Host Immune Evasion by Lyme and Relapsing Fever Borreliae:

Findings to Lead Future Studies for Borrelia miyamotoi. Front. Immunol. 8:12. doi: 10.3389/fimmu.2017.00012

\section{Brandee L. Stone and Catherine A. Brissette* \\ Department of Biomedical Sciences, School of Medicine and Health Sciences, University of North Dakota, Grand Forks, ND, USA}

The emerging pathogen, Borrelia miyamotoi, is a relapsing fever spirochete vectored by the same species of Ixodes ticks that carry the causative agents of Lyme disease in the US, Europe, and Asia. Symptoms caused by infection with B. miyamotoi are similar to a relapsing fever infection. However, $B$. miyamotoi has adapted to different vectors and reservoirs, which could result in unique physiology, including immune evasion mechanisms. Lyme Borrelia utilize a combination of Ixodes-produced inhibitors and native proteins [i.e., factor $\mathrm{H}$-binding proteins (FHBPs)/complement regulator-acquiring surface proteins, p43, BBK32, BGA66, BGA71, CD59-like protein] to inhibit complement, while some relapsing fever spirochetes use $\mathrm{C} 4 \mathrm{~b}$-binding protein and likely Ornithodorosproduced inhibitors. To evade the humoral response, Borrelia utilize antigenic variation of either outer surface proteins (Osps) and the Vmp-like sequences (VIs) system (Lyme borreliae) or variable membrane proteins (Vmps, relapsing fever borreliae). B. miyamotoi possesses putative FHBPs and antigenic variation of Vmps has been demonstrated. This review summarizes and compares the common mechanisms utilized by Lyme and relapsing fever spirochetes, as well as the current state of understanding immune evasion by B. miyamotoi.

Keywords: Borrelia miyamotoi, spirochetes, relapsing fever, Lyme disease, complement, factor $\mathrm{H}$, antigenic variation, immune response

\section{INTRODUCTION}

Tick-borne diseases are among the top reported diseases to the US Centers for Disease Control and Prevention. This group of diseases include an array of viral, bacterial, and parasitic pathogens (e.g., Lyme disease, tick-borne relapsing fever, anaplasmosis, rickettsiosis, Powassan virus, tickborne encephalitis virus, Colorado tick fever, Heartland virus, babesisosis) transmitted by the bite of certain species of hard and soft shell ticks from four genera (Ixodes, Dermacentor, Amblyomma, Ornithodoros) (1-3).

Intense research efforts are occurring worldwide in an attempt to understand, detect, control, treat, and eradicate these pathogens and their diseases. One step toward preventing and treating infectious diseases is to understand how pathogens evade host defenses to establish infection. Pathogenic Lyme and relapsing fever borreliae establish infection through one or more of the following mechanisms: physical barriers (e.g., slime layer of glycoproteins), migration to 
immunoprivileged sites, and hijacking host processes [e.g., inactivation of complement with factor $\mathrm{H}$-binding proteins (FHBPs)]. The mechanisms utilized by the emerging relapsing fever pathogen, Borrelia miyamotoi, are currently uncharacterized. Herein, we review some mechanisms Lyme and relapsing fever Borrelia utilize to inhibit and evade host complement and humoral immune responses and relate these to mechanisms that might be used by $B$. miyamotoi.

\section{Lyme Disease and Tick-Borne Relapsing Fever: Spirochetes, Vectors, and Diseases}

Approximately 20 closely related pathogenic and non-pathogenic species of Borrelia form the B. burgdorferi sensu lato complex. Of these 20 species, at least five are classified as causative agents of Lyme disease (US: B. burgdorferi sensu stricto; Europe and Asia: B. afzelii, B. garinii, B. spielmanii, B. bavariensis) (4-10). Lyme borreliae are carried and transmitted by several species of Ixodes ticks (Ixodidae, hard shell) though the most common species are I. scapularis and I. pacificus in the US and I. ricinus and I. persulcatus in Europe and Asia.

Species of Ornithodoros ticks (Argasidae, soft shell) carry and transmit relapsing fever spirochetes. Several Borrelia spp. cause relapsing fever but $B$. hermsii, $B$. turicatae, $B$. crocidurae, $B$. hispanica, B. duttonii are more commonly encountered.

While the general rule is Ixodes transmit spirochetes of the B. burgdorferi s.l. complex and Ornithodoros transmit relapsing fever borreliae, there are exceptions. B. recurrentis is a louseborne relapsing fever spirochete endemic mainly to sub-Saharan Africa. B. theileri causes bovine borreliosis and is transmitted by Rhipicephalus microplus, a hard shell tick that parasitizes livestock (11). B. lonestari and B. turcica, spirochetes genetically similar to relapsing fever borreliae, are found in the hard shell ticks, Amblyomma americanum and Hyalomma aegyptium, respectively $(12,13)$. Finally, $B$. miyamoto $i$ is a relapsing fever spirochete vectored by the same Ixodes spp. that transmit species of the B. burgdorferi s.l. complex.

In terms of disease, several tick-borne diseases are associated with non-specific symptoms (i.e., a possibly self-limiting "influenza-like" illness characterized by malaise, fatigue, aches, fever, and chills) (Table 1). While infection with Borrelia spp. generally results in similar symptoms, some species-specific symptoms can arise $(14,15)$. Erythema migrans and arthritis are commonly associated with a B. burgdorferi s.s. infection but rarely with $B$. afzelii infection, which more commonly manifests in the dermatological condition, acrodermatitis chronica atrophicans. B. garinii is more commonly associated with neurological symptoms. Relapsing fever is characterized by recurring spirochetemia corresponding to recurrent episodes of high fever not seen with B. burgdorferi s.l. infections.

\section{Borrelia miyamotoi}

Borrelia miyamotoi s.s. strains were first isolated and cultured in Japan in 1995 from I. persulcatus and the blood of Apodemus argenteus (small Japanese field mouse) (16). Since this initial isolation, B. miyamotoi DNA has been identified in I. scapularis,
I. pacificus, I. ricinus, and I. persulcatus across the Northern hemisphere (17-84). B. miyamotoi DNA has also been identified in humans with a suspected tick-borne disease; while B. miyamotoi is associated with disease, teasing out the details of an infection with this spirochete has proven difficult for several reasons (85-92).

First, diagnoses based on serology can be problematic and lead to false-negative diagnoses. Several antigens, including 4 of the 10 assayed in a Lyme Western blot, are shared among Lyme, relapsing fever, and B. miyamotoi spirochetes $(93,94)$. Although Lyme and relapsing fever Borrelia cause different diseases and occupy different niches, species in this genus share a high degree of genetic homology (95-98). Therefore, some degree of cross-reactivity occurs between B. miyamotoi antibodies and B. burgdorferi s.l. antigens (91).

Second, an adequate and appropriate immunocompetent animal model to study B. miyamoto $i$ infection is only now beginning to take shape. Without an optimal animal model to identify characteristic symptoms and pathologies, we are left to interpret and extrapolate symptoms from complex human cases where disease pathology can be complicated by underlying or unreported medical conditions or coinfections. Previous attempts to infect immunocompetent Peromyscus leucopus mice (a common reservoir for $B$. burgdorferi in the US) with B. miyamotoi s.l. LB-2001 (US strain) had been unsuccessful leaving severe combined immune deficient (SCID) mice as the only available animal model (17). SCID mice infected with $B$. miyamotoi exhibit sustained spirochetemia, similar to infection with relapsing fever spirochetes (99). Recently, however, Wagemakers et al. (100) were able to successfully infect immunocompetent $\mathrm{C} 3 \mathrm{H} / \mathrm{HeN}$ mice with LB-2001 and demonstrate spirochetemia 2 days post infection (dpi). Three of the eight mice infected exhibited relapsing spirochetemia at 5 and $6 \mathrm{dpi}$. More studies are required to determine the optimal animal model for B. miyamotoi infection (101-103).

Finally, B. miyamotoi's status as a pathogen has only recently been established. The first confirmed human infections were reported in Russia in 2011 (85) with more cases subsequently described in the US, Europe, and Japan (86-91, 104-107).

\section{B. miyamotoi Infection and Disease}

Much of the data available on B. miyamotoi infections come from retrospective serological analyses of banked patient samples, which provide valuable epidemiological information but can lack the detailed patient history or clinical aspects required to sufficiently define a disease. The available data depict an illness, currently termed B. miyamotoi disease or hard tick-borne relapsing fever that is similar to relapsing fever.

The patients described by Platonov et al. (85) reported tick bites, developed moderate or severe disease, and were hospitalized as a precautionary measure against more severe tick-borne diseases, particularly viral tick-borne encephalitis. In total, 46 patients were classified as having a confirmed B. miyamotoi infection with no detected current $B$. burgdorferi s.l. coinfection by PCR. Sera from all 46 patients reacted with whole cell lysates of B. burgdorferi, B. afzelii, and B. garinii. The most common 
TABLE 1 | Overview of Borrelia diseases.

\begin{tabular}{|c|c|c|c|}
\hline Disease & Vector $^{a}$ & Causative agent(s) ${ }^{a}$ & Clinical symptom(s) \\
\hline Lyme disease & $\begin{array}{l}\text { I. scapularis (USA) } \\
\text { I. pacificus (USA) } \\
\text { I. ricinus (Europe, } \\
\text { Asia) } \\
\text { I. persulcatus } \\
\text { (Europe, Asia) }\end{array}$ & $\begin{array}{l}\text { B. burgdorferi sensu stricto (USA) } \\
\text { B. afzelii (Europe, Asia) } \\
\text { B. bavariensis (Europe, Asia; formerly } \\
\text { B. garinii OspA serotype 4) } \\
\text { B. garinii (Europe, Asia) } \\
\text { B. spielmanii (Europe, Asia) }\end{array}$ & $\begin{array}{l}\text { Symptom onset after exposure: early stage generally 3-30 days } \\
\text { Influenza-like (e.g., mild fever, malaise, myalgia/arthralgia; B. burgdorferi s.s.) } \\
\text { Erythema migrans (B. burgdorferi s.s., B. afzelii) } \\
\text { Symptom onset after exposure: late stage generally > } 30 \text { days } \\
\text { Arthritis } \\
\text { Acrodermatitis chronica atrophicans (B. afzelii) } \\
\text { Neurological (Lyme neuroborreliosis, e.g., numbness, Bell's palsy, stiffness } \\
\text { of neck, declining memory, sleep disorders; B. burgdorferi s.s., B. bavariensis) }\end{array}$ \\
\hline $\begin{array}{l}\text { Tick-borne relapsing } \\
\text { fever }\end{array}$ & $\begin{array}{l}\text { O. hermsi } \\
\text { O. turicata } \\
\text { O. parkeri } \\
\text { O. moubata }\end{array}$ & $\begin{array}{l}\text { B. hermsii } \\
\text { B. turicatae } \\
\text { B. parkerii } \\
\text { B. duttonii }\end{array}$ & $\begin{array}{l}\text { Symptom onset: ca. } 7 \text { days } \\
\text { Influenza-like } \\
\text { Recurring high fever } \\
\text { Headache } \\
\text { Myalgia } \\
\text { Arthritis } \\
\text { Approximately } 3-10 \text { febrile episodes (relapses) occur; mortality rates are } \\
\text { variable but generally less than } 5 \%\end{array}$ \\
\hline $\begin{array}{l}\text { Hard tick-borne } \\
\text { relapsing fever/Borrelia } \\
\text { miyamotoi disease }\end{array}$ & $\begin{array}{l}\text { I. scapularis } \\
\text { I pacificus } \\
\text { I ricinus } \\
\text { I. persulcatus }\end{array}$ & B. miyamotoi & $\begin{array}{l}\text { Symptom onset after exposure: ca. } 15 \text { days (85) } \\
\text { Influenza-like } \\
\text { Most common: } \\
\text { Fever } \\
\text { Malaise } \\
\text { Headache } \\
\text { Chills } \\
\text { Arthritis/arthralgia } \\
\text { Meningoencephalitis (immunocompromised patients) } \\
\text { Rare (less than 10\% of patients): } \\
\text { Rash/erythema migrans } \\
\text { Gastrointestinal (e.g., vomiting, nausea, diarrhea) } \\
\text { Cardiac/respiratory (shortness of breath) } \\
\text { Neurological (e.g., dizziness, confusion) } \\
\text { Stiffness of neck }\end{array}$ \\
\hline $\begin{array}{l}\text { Louse-borne relapsing } \\
\text { fever }\end{array}$ & $\begin{array}{l}\text { P. humanus } \\
\text { humanus }\end{array}$ & B. recurrentis & $\begin{array}{l}\text { Symptom onset after exposure: ca. 4-8 days } \\
\text { Recurring high fever } \\
\text { Malaise } \\
\text { Headache } \\
\text { Chills } \\
\text { Meningism } \\
\text { Myalgia } \\
\text { Nausea } \\
\text { Vomiting } \\
\text { Approximately } 3-5 \text { relapses occur; mortality rate varies greatly } \\
\text { (30-70\% without treatment during outbreaks) }\end{array}$ \\
\hline
\end{tabular}

${ }^{a}$ Commonly encountered and studied vectors and causative agents are listed.

symptoms were fever, headache, and malaise or fatigue (Table 2). Five patients reported recurrent fever with an average duration of 3.4 days, and 9 days between relapses, similar to infections with relapsing fever spirochetes. All patients were successfully treated with ceftriaxone or doxycycline.

A similar series of cases were reported in the US in 2015 (91). Ninety-seven of 11,515 patient samples submitted by clinical laboratories for tick-borne disease analysis were PCRpositive for B. miyamotoi. Patients with known or suspected $B$. burgdorferi coinfection or a history of Lyme disease were omitted from further analysis. Fever, headache, and malaise were commonly reported among US patients with two patients reporting recurrent fever (Table 2). The duration of febrile episodes and the time between relapses were not reported. Spirochetemia was noted in US patients but was either not reported or documented in Russian patients. Strikingly, a rash or single erythema migrans of unknown origin was reported in 8 and $9 \%$ of US and Russian patients, respectively.

Some symptoms were different between the US and Russia patients, which suggest clinical manifestations vary by $B$. miyamotoi strain, similar to that seen with B. burgdorferi s.l. strains (Table 2) (108). Arthralgia was more common in US (76\%) compared to Russian patients (28\%), and leukopenia, thrombocytopenia, and elevated liver enzymes were found in some US patients but in none of the Russian patients. These differences may be explained by genetic differences between American 
TABLE 2 | Comparison of symptoms reported from US (91) and Russian (85) patients.

\begin{tabular}{|c|c|c|}
\hline Symptom & US $(n=51)$ & Russia $(n=46)$ \\
\hline Fever, chills & $96 \%$ & $98 \%, 35 \%$ a \\
\hline Headache & $96 \%$ & $89 \%$ \\
\hline Myalgia & $84 \%$ & $59 \%$ \\
\hline Arthralgia & $76 \%$ & $28 \%$ \\
\hline Malaise/fatigue & $82 \%$ & $98 \%$ \\
\hline Rash/EMc ${ }^{c}$ & $8 \%$ & $9 \%$ \\
\hline Gastrointestinal symptoms ${ }^{d}$ & $6 \%$ & $\begin{array}{l}30 \% \text { (nausea) } \\
7 \% \text { (vomiting) }\end{array}$ \\
\hline Respiratory symptoms ${ }^{e}$ & $6 \%$ & na \\
\hline $\begin{array}{l}\text { Neurological symptoms } \\
\text { (dizziness, confusion, vertigo) }\end{array}$ & $8 \%$ & na \\
\hline Stiff neck & na & $2 \%$ \\
\hline
\end{tabular}

${ }^{a}$ Fever and chills were reported in separate categories.

${ }^{b}$ Authors noted in most patients the headaches were severe.

¿US patients were described as having a rash. Russian patients were noted for having a single erythema migrans.

'For US patients, Gl symptoms included nausea, abdominal pain, diarrhea, anorexia.

For Russian patients, Gl symptoms included nausea and vomiting.

eLabored breathing or short of breath.

${ }^{f}$ Not reported.

and Asian type B. miyamotoi. Genetic analyses of B. miyamotoi isolates have revealed heterogeneity between, and a high degree of homology among, strains from the US (American types; I. scapularis, I. pacificus), Europe (European type; I. ricinus), and Asia (Asian type; I. persulcatus) $(59,109)$.

Detailed case reports are currently available for nine patients in the US, Europe, and Japan. For immunocompetent patients, symptoms were similar to those observed in the aforementioned studies (e.g., fever, headache, malaise) $(86,89$, $90,106,107)$. One US patient did not seek treatment, providing additional evidence that $B$. miyamoto $i$ can result in recurrent fever and be self-resolving, similar to other relapsing fever infections $(92,110)$. This patient experienced two episodes of fever separated by 3 weeks, significantly longer than in other B. miyamotoi or relapsing fever patients, with each episode lasting 4-5 days, on par with B. miyamotoi or relapsing fever patients.

The pathology of $B$. miyamotoi infection is dramatically different in immunocompromised patients, specifically those treated for non-Hodgkin's lymphoma (NHL) with rituximab. Two patients treated with rituximab for NHL, one from the US (88) and one from the Netherlands (87), with reported recent tick bites developed meningoencephalitis. Motile spirochetes were detected in cerebral spinal fluid in both cases. Interestingly, $g l p Q$ was amplified and sequenced from both patient's samples yet no anti-GlpQ antibodies were detected in the blood or cerebral spinal fluid of the European patient. IgM against $B$. burgdorferi was negative for both patients. Neither patient reported any of the commonly associated symptoms of a B. miyamotoi infection (e.g., fever, headache, myalgia, malaise). Instead, both patients exhibited neurological symptoms (cognitive processing defects, disturbed gait). A third patient from Germany, also treated with rituximab for NHL, developed Lyme neuroborreliosis-like symptoms (dizziness, vomiting, and headache) (111).

\section{THE COMPLEMENT SYSTEM}

The complement system, composed of the classical, lectin, and alternative branches, is a crucial component of the immune system (Figure 1). Components of complement continuously circulate in blood making complement one of the first lines of defense against pathogens. Complement initiates an immune response by: (1) triggering phagocytosis through opsonization, (2) mediating inflammation through the release of chemotactic peptides, and (3) lysing cells via the membrane attack complex (MAC, also called the terminal complement complex or TCC) (Figure 1) (112).

The classical pathway is generally mediated by non-specific antibodies, immunoglobulin G (IgG) or IgM, binding a bacterial antigen. Importantly, recent studies have shown Borreliaspecific IgM is produced by a subset of B cells during infection and plays a crucial role in clearing Borrelia (113-121). The C1 complex, composed of $\mathrm{C} 1 \mathrm{q}, \mathrm{C} 1 \mathrm{r}$, and $\mathrm{C} 1 \mathrm{~s}$, forms upon recognition of bound IgG or IgM. C1 cleaves C2 (C2a, C2b) and C4 (C4a, C4b). C4b covalently binds the target's cell surface and complexes with $\mathrm{C} 2 \mathrm{a}$ to form $\mathrm{C} 3$ convertase, which cleaves $\mathrm{C} 3$ into $\mathrm{C} 3 \mathrm{a}$ and $\mathrm{C} 3 \mathrm{~b}$. C3b covalently binds the target cell surface (opsonization, facilitates phagocytosis of foreign cells and cellular debris), while $\mathrm{C} 3 \mathrm{a}$ remains soluble to act as a mediator of inflammation. C5 convertase forms when $\mathrm{C} 3 \mathrm{~b}$ binds $\mathrm{C} 3$ convertase. Not surprisingly, C5 convertase cleaves C5 into C5a, a soluble inflammatory mediator, and C5b. C5b binds the target cell surface and C6 forming C5b6, which binds C7 (C5b-7) then C8. The C5b-8 complex binds C9 (C5b-9) and facilitates polymerization of several additional C9 proteins. These polymerized C9 proteins form the transmembrane pore of the MAC allowing an influx of extracellular fluid and subsequent lysis of the target cell.

The lectin pathway is very similar to the classical pathway, differing only in the initiation steps. The lectin pathway is typically initiated through mannose-binding lectins, a group of pattern recognition receptors (PRRs) on host cells, binding specific sets of carbohydrates on foreign cells (pathogen-associated molecular patterns, PAMPs). The lectin and classical pathways converge at the cleavage of $\mathrm{C} 2$ and $\mathrm{C} 4$ by different mechanisms. In the lectin pathway, C4 and C2 cleavage occurs through mannose-binding lectin-associated serine proteases (112).

Like the classical and lectin pathways, the alternative pathway forms a C3 convertase, C5 convertase, and results in the formation of the MAC. Unlike the classical and lectin pathways, the alternative pathway may not require antibody-antigen or PAMP-PRR interactions for activation. Rather, this pathway is initiated through hydrolysis of $\mathrm{C} 3$ to $\mathrm{C} 3\left(\mathrm{H}_{2} \mathrm{O}\right)$, which is thought to occur continuously at low levels. The pathway is propagated through interactions with bacterial antigens or a lack of host surface markers (e.g., sialic acid, glycosaminoglycans, sulfated polysaccharides) (112).

Factor $\mathrm{B}$, after binding $\mathrm{C} 3\left(\mathrm{H}_{2} \mathrm{O}\right)$, is cleaved by factor $\mathrm{D}$ into $\mathrm{Ba}$ and $\mathrm{Bb}$ resulting in $\mathrm{C} 3\left(\mathrm{H}_{2} \mathrm{O}\right) \mathrm{Bb}$, the fluid-phase $\mathrm{C} 3$ convertase (cleaves $\mathrm{C} 3$ to $\mathrm{C} 3 \mathrm{a}$ and $\mathrm{C} 3 \mathrm{~b}$ ). $\mathrm{C} 3 \mathrm{~b}$ binds the bacterial cell surface where it complexes with additional factor B. Factor D again cleaves factor $\mathrm{B}$, which results in the second, predominant and 


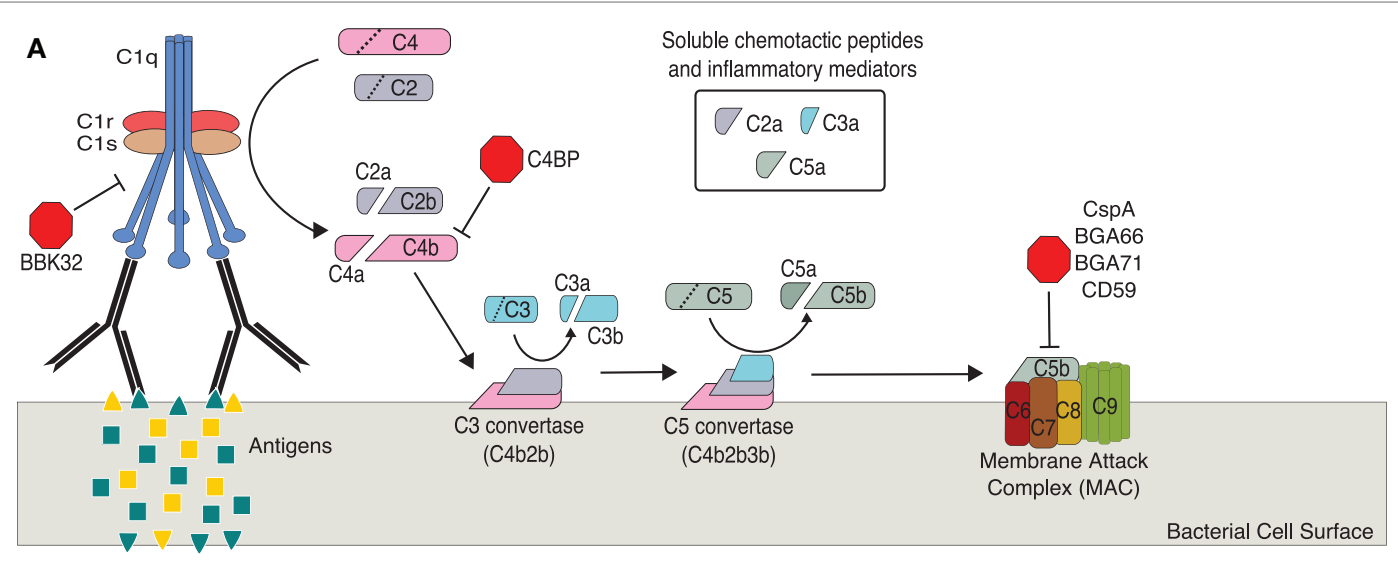

B
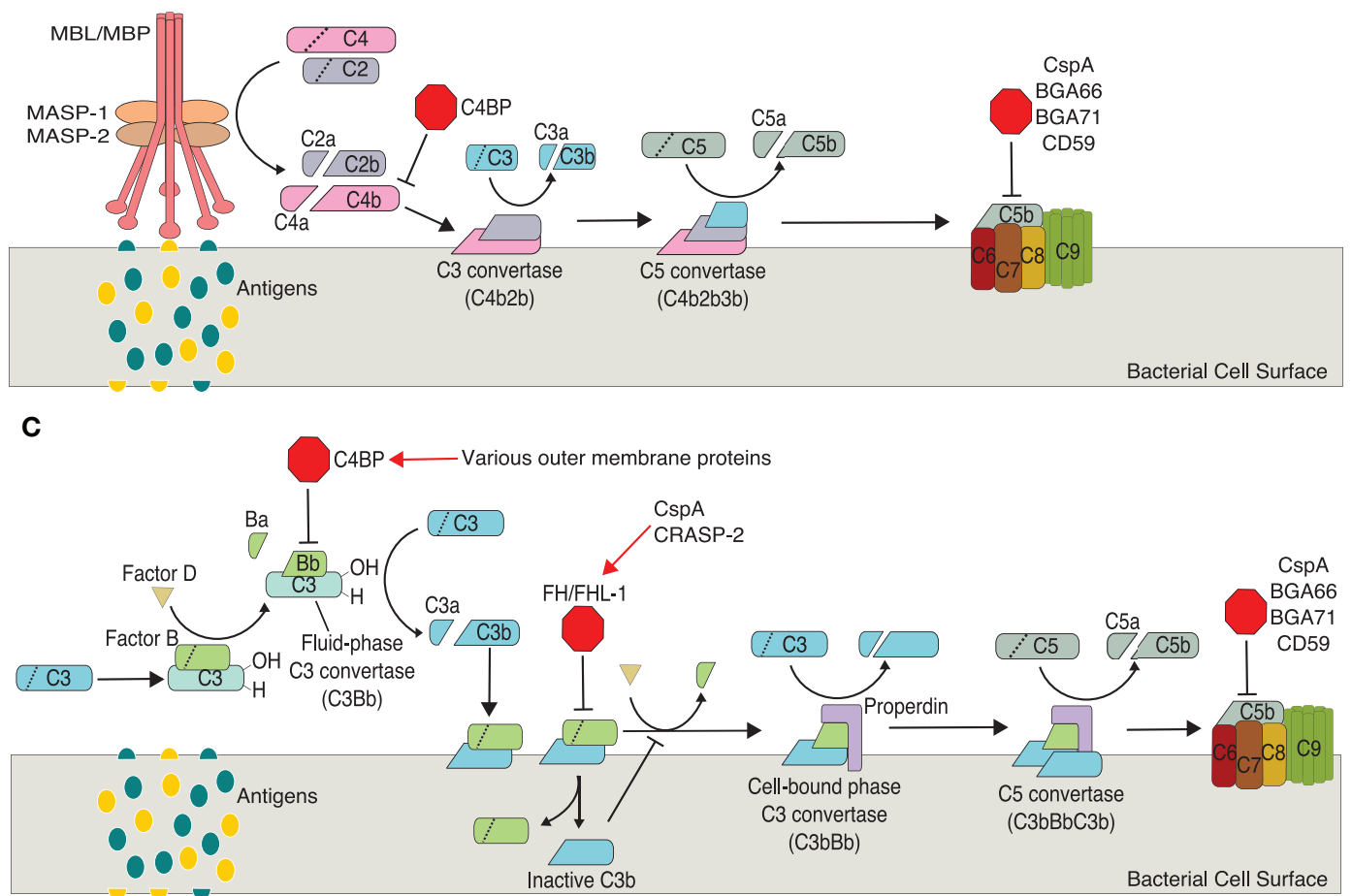

FIGURE 1 | Activation and regulation of complement pathways relevant to Borrelia spp. infection. (A) Classical pathway. (B) Mannose-lectin pathway. (C) Alternative pathway. Points of complement inhibition utilized by Borrelia spp. are indicated by red octagons. Red arrows indicate borrelial proteins that interact with host regulatory proteins.

cell-bound $\mathrm{C} 3$ convertase $(\mathrm{C} 3 \mathrm{bBb})$. This cell-bound $\mathrm{C} 3$ convertase is stabilized by properdin $(\mathrm{C} 3 \mathrm{bBbP})$. Binding of additional $\mathrm{C} 3 \mathrm{~b}$ to $\mathrm{C} 3$ convertase results in the formation of $\mathrm{C} 5$ convertase ( $\mathrm{C} 3 \mathrm{bBbC} 3 \mathrm{~b})$, which cleaves $\mathrm{C} 5$ and initiates the formation of the MAC as described above.

\section{INHIBITION OF THE MAMMALIAN COMPLEMENT SYSTEM BY Borrelia AND Ixodes}

Regulation of complement is critical for survival of host cells (122, 123). Numerous mechanisms have evolved in hosts to prevent aberrant activation of complement on host cells including the use of complement regulatory factors and host cell surface components (e.g., sialic acid). Pathogens that inhibit host complement use mechanisms that are inextricably tied to host regulatory processes. Borrelia use several native proteins to inhibit complement [i.e., FHBPs or complement regulator-acquiring surface proteins (CRASPs), p43, BBK32, BGA66, BGA71, CD59-like protein] (124). The following sections focus on the complement regulators factor $\mathrm{H}(\mathrm{FH})$, factor $\mathrm{H}$-like protein-1 (FHL-1), factor I (FI), C4b-binding protein (C4BP), and CD59.

At least for Lyme borreliae, resistance to complement varies by strain and species (125-130). Roughly, 10\% of B. burgdorferi s.s. are serum resistant, and $90 \%$ are intermediately resistant 
to serum; $75 \%$ of B. afzelii isolates are resistant, and $25 \%$ are intermediate; $100 \%$ of $B$. garinii isolates are sensitive (specifically, OspA serotypes 3, 5, 6, 7); B. bavariensis (formerly B. garinii OspA serotype 4) is intermediately resistant. To the best of our knowledge, similar comparisons of multiple strains and species have not been published for relapsing fever Borrelia, though complement resistance is not universal among relapsing fever species among the strains observed. Resistance to complement is important for the transmission, survival, and dissemination of some Borrelia spp. in mammalian and rodent hosts and reservoirs (131). Many Borrelia spp., particularly Lyme borreliae, are masters of complement evasion due to the native anticomplement proteins some possess and the ability all infectious strains possess to co-opt tick and host complement regulatory proteins.

\section{FH, FHL-1, and FI}

Factor $\mathrm{H}$ is an ubiquitous $150-\mathrm{kDa}$ soluble protein produced by diverse cell types throughout the human body (e.g., hepatic cells, fibroblasts, monocytes, endothelial cells) (132). FH consists of 20 short consensus repeats, while FHL-1 is a truncated variant of $\mathrm{FH}$ consisting of the $\mathrm{FH} \mathrm{N}$-terminal short consensus repeats 1 through 7. Both FH and FHL-1 are major direct regulators of the alternative complement pathway. In addition, FH and FHL-1 can directly regulate the classical and lectin pathways, though the regulatory roles in these pathways are minor compared to other classical and lectin regulatory mechanisms. Regulation is achieved through the recognition of self and non-self molecules via domains located on the C-and $\mathrm{N}$-terminals, respectively (133-135). The C-terminal discriminates self from non-self through interactions with sialic acids, glycosaminoglycans, and sulfated polysaccharides, which are typically found only on host cells (136-140). FH binds self molecules with high affinity to prevent activation of complement. FH regulates the classical and lectin pathways by acting as a co-factor for FI. In this capacity, FH facilitates the serine protease activity of FI in cleaving and inactivating $\mathrm{C} 3 \mathrm{~b}$. The alternative pathway is regulated through $\mathrm{FH}$ targeting factor $\mathrm{Bb}$, which prevents the formation of fluid-phase $\mathrm{C} 3$ convertase and promotes decay ("decay acceleration activity") of $\mathrm{C} 3$ and C5 convertases (141). For comprehensive reviews of FH and FHL-1, see Ref. $(132,141,142)$.

\section{FHBPs and CRASPs}

Interactions with $\mathrm{FH}$ are the best-studied mechanism for Borrelia complement inactivation, and complement resistance is correlated with binding FH (143). Borrelia spp. bind FH and/ or FHL-1 through various native proteins collectively termed FHBPs or CRASPs $(125,144,145)$. CRASPs can be grouped by their ability to bind only FH or both FH and FHL-1 as well as the species specificity of binding (that is, whether a FHBP can bind FH from only one or several host species) $(125,145)$ : CRASP-1 (CspA) and CRASP-2 (CspZ) bind both FH and FHL-1, while CRASP-3 (ErpP), CRASP-4 (ErpC), and CRASP-5 (ErpA) bind only $\mathrm{FH}$. CRASPs bind soluble $\mathrm{FH}$ and maintain it in an active conformation thereby allowing $\mathrm{FH}$ to inhibit completion of the complement response (i.e., MAC formation).
Several relapsing fever spirochetes bind $\mathrm{FH}$ in vitro (125, 146-151). Two FHBPs, FhbA and BhCRASP-1, have been identified in B. hermsii strains YOR and HS1, respectively $(152,153)$. However, binding $\mathrm{FH}$ is not as important for relapsing fever spirochetes to establish infection as it is for Lyme disease Borrelia $(154,155)$. Further supporting the non-essential nature of binding FH, Woodman et al. (154) found that despite FhbA being surface exposed and strongly binding $\mathrm{FH}$ in vitro, only $16 \%$ of $B$. hermsii recovered from the blood of infected mice had detectable levels of bound $\mathrm{FH}$.

\section{C4b-Binding Protein}

$\mathrm{C} 4 \mathrm{~b}$-binding protein $(\mathrm{C} 4 \mathrm{BP})$ has regulatory roles in all three pathways, though is the major regulator of the classical and lectin pathways. C4BP facilitates inactivation of $\mathrm{C} 4 \mathrm{~b}$ (classical, lectin) and fluid-phase $\mathrm{C} 3 \mathrm{~b}$ (alternative) by binding $\mathrm{C} 4 \mathrm{~b}$, displacing $\mathrm{C} 2 \mathrm{a}$, and facilitating FI-mediated inactivation of C3 and C5 convertases (156).

Some Lyme and relapsing fever Borrelia spp. bind human and various animal C4BP $(143,148,149,157,158)$. A comprehensive analysis identified outer surface proteins (Osps) associated with C4BP including OspA, Vlps, variable membrane proteins (Vmps), and several unidentified Osps (159). However, other studies have observed no binding of C4BP by Borrelia spp (143, $150,160)$. These contradictory data may be due to differences in experimental design including the use of different strains, growth medium, temperatures, growth phases, and the use of recombinant versus native human C4BP. A putative C4BP receptor, $\mathrm{p} 43$, has been identified in B. burgdorferi s.l. (157). The relapsing fever spirochetes $B$. recurrentis and B. duttonii produce CihC, a surface lipoprotein homologous in sequence and function to fibronectinbinding proteins of other relapsing fever spirochetes, which also binds C4BP (148).

\section{FHBP, C4BP, and Borrelia Niche}

Resistance to complement is positively correlated to the infectivity of some Borrelia strains (130). With a higher resistance to complement, the more likely a bacterium can survive, disseminate, and proliferate. Co-opting tick proteins will protect spirochetes during the initial stages of transmission and dissemination but sustained dissemination requires Borrelia to resist complement via its own native mechanisms.

This leads to the question of how complement sensitive strains can cause infection. An interesting hypothesis was developed regarding complement resistance and spirochete niche when a relationship was noted between binding of the complement inhibitors, C4BP and FH $(157,158,161)$. Neurotropic strains (e.g., B. bavariensis, B. garinii, B. turicatae, B. duttonii, and to a lesser extent $B$. hermsii) do not have to be highly resistant to complement in immunoprivileged sites, such as the central nervous system. Finding neurotropic species strongly bind C4BP and very weakly bind FH and FHL-1, while species that are not neurotropic bind C4BP but preferentially bind $\mathrm{FH}$ and/ or FHL-1 supports this hypothesis (157). Alitalo et al. (162) did find B. garinii strains isolated from neuroborreliosis patients not only express FHBPs not expressed by strains cultured in vitro 
for an extended time but the FHBPs also bind FH. This implies complement resistance, though this was not reported and one of the isolates (LU59) was later reported to be highly but not completely sensitive to complement (163). It is possible that strong binding of $\mathrm{FH}$ is an artifact seen in vitro, similar to that observed with relapsing fever spirochetes (see FHBPs and CRASPs). Thus, binding $\mathrm{FH}$ is not required for neurotropic strains. Perhaps C4BP is sufficient to prevent complement activation during migration of neurotropic species from the site of inoculation to immunoprivileged sites. On the other hand, binding FH may be important for neurotropic strains to resist complement during migration and the incomplete sensitivity observed by Sandholm et al. (158) may be due to in vitro culturing resulting in the population losing its ability to bind $\mathrm{FH}$. It could also be that neither C4BP nor FHBPs play a role in complement-sensitive borreliae disseminating and a novel mechanism is utilized by complement-sensitive strains.

\section{CD59-Like Protein}

Little information is available regarding the CD59-like protein of B. burgdorferi. Pausa et al. (164) demonstrated an increase in serum sensitivity and MAC formation in a serum-resistant B. burgdorferi isolate treated with anti-CD59 antibodies compared to the control treated B. burgdorferi and the serumsensitive B. garinii isolate. In eukaryotic cells, CD59 is a surfaceexposed membrane protein that prevents C9 polymerization and thus the formation of the MAC $(19,20)$. Still, it is not clear Borrelia possesses a protein homologous to mammalian or rodent CD59. While human anti-CD59 antibodies bound a surface-exposed integral membrane protein $(29 \mathrm{kDa})$, this protein has never been identified though several known borrelial proteins can and have been ruled out based on molecular weight (e.g., BGA66, BGA71, OspA, OspB, OspC) (124). Given the demonstrated complement resistance conferred by this unknown borrelial protein, more attention should be given to identifying and clarifying the role this protein plays in complement resistance.

\section{Complement Inhibition by Ixodes and Ornithodoros Salivary Proteins}

A large number of proteins with a vast array of functions have been identified in the saliva of feeding Ixodes spp. with more being identified and characterized (165-169). While the details and mechanisms for some of these proteins remain to be elucidated, the beneficial nature of Ixodes salivary proteins to spirochete transmission and survival has been established (170-177). Ixodes saliva contains adaptive and innate immunomodulatory and anticomplement proteins $(165,178-183)$. A recent study demonstrated changes in the salivary protein profile over the course of a feeding, which has implications for the efficacy of the host immune response at the feeding pit and for transmitting spirochetes (168). Currently, several members of the anticomplement family of proteins have been characterized from I. scapularis, I. ricinus, and I. persulcatus including Salp15, Salp20, Isac, Irac I, Irac II, and Ixac-B1, -2, -3, -4, -5.
Salp15 is able to inhibit both adaptive and innate immune responses $(184,185)$. Salp15 binds OspC, which both serumresistant and serum-sensitive B. burgdorferi s.l. produce, to inhibit deposition of the MAC and block the recognition and binding of antibodies to OspC (172, 186-188). In addition, Salp15 expression increases when ticks are infected with $B$. burgdorferi (172). Interestingly, mice passively immunized with anti-Salp15 antibodies were protected from infection with $B$. burgdorferi (189).

Salp20 inhibits the alternative complement pathway through binding properdin, which prevents stabilization of C3 convertase and propagation of the alternative pathway $(183,190,191)$. In addition, Salp20 enhances the activity of FH to inhibit the alternative pathway (183). Incubating a serum-sensitive B. garinii strain with Salp20 protected the strain from complement activation and lysis (190). The mechanism(s) by which Salp20 confer(s) protection to $B$. garinii is unknown.

The Isac-like family of proteins include Ixodes scapularis anticomplement (Isac), I. ricinus anticomplement (Irac I), Irac II, and Ixac-B1 through -5 (I. ricinus anticomplement). Proteins in this family are similar in function to Salp20 $(180,182,192)$. Inhibition of the alternative complement pathway is achieved through targeting $\mathrm{C} 3$ convertase via interactions with properdin, as Salp20 does, and by preventing factor B from binding C3b or displacing factor B from C3 convertase.

Ornithodoros salivary gland extracts also possess proteins that inhibit the host immune response (193). To date, however, one complement inhibitor has been identified and characterized from one Ornithodoros spp. O. moubata, found in Africa, is the vector of the relapsing fever spirochete B. duttonii (194). O. moubata complement inhibitor $(\mathrm{OmCI})$ is a lipocalin that binds to and prevents cleavage of C5 $(195,196)$. OmCI was found to be effective at inhibiting C5 cleavage in different mammalian and rodent hosts (196). It is unknown if OmCI protects $B$. duttonii or if homologous proteins are found in other Ornithodoros spp.

\section{EVASION BY Borrelia OF THE MAMMALIAN HUMORAL IMMUNE RESPONSE BY SURFACE PROTEIN VARIATION}

Evasion of complement is undoubtedly a vital mechanism to ensure spirochetes survive and establish infection. However, Borrelia will elicit an humoral immune response, and there are clear roles for this immune response in controlling and preventing Borrelia infection $(113-118,197,198)$. These responses form the basis of an intense research effort for effective Lyme vaccines. Fortunately for Borrelia, they are quite adept at evading the host humoral response primarily through variation of surface-exposed proteins. Lyme disease Borrelia possess Osps and variable membrane protein-like [Vmp-like sequences (Vls)] proteins, while relapsing fever Borrelia possess Vmps (includes variable large and variable small proteins) (199-203). Some species hide antigens by inducing erythrocyte rosetting (204). 


\section{Osps and VlsE of Lyme Borrelia}

The Osps, particularly OspC, are one of the most studied group of Borrelia proteins. For comprehensive reviews of Borrelia Osps, see Ref. $(145,205,206)$. OspE and OspF are discussed above with FHBPs. Less is known about OspA, a protein predominantly involved in uptake and survival in ticks. OspA is immunogenic and able to block antibody binding to another surface-exposed protein, P66 $(207,208)$.

OspC has diverse roles, many of which are essential for transmission from Ixodes and establishing infection in mammals (209-216). These studies were key in demonstrating that $\operatorname{ospC}$ is upregulated during the early stages of infection, downregulated after infection has been established, and deleting or overexpressing $\operatorname{ss} p C$ results in spirochetes that are quickly cleared from a host.

A handful of immune evasion functions have been identified for OspC. As discussed above, OspC protects Borrelia by binding Salp15. OspC also prevents phagocytosis by macrophages (216). In addition, several OspC types have been identified and correlated with a strains ability to establish infection in hosts and reservoirs (217-222). However, as each Osp is present as a singlecopy locus, genetic variation is seen at the population level. That is, outside of random mutation or horizontal gene transfer events, a single spirochete cannot produce different OspC types in situ.

In contrast, the Vls system can change the expressed surface antigen in situ (Figure 2). Antigenic recombination of VlsE is

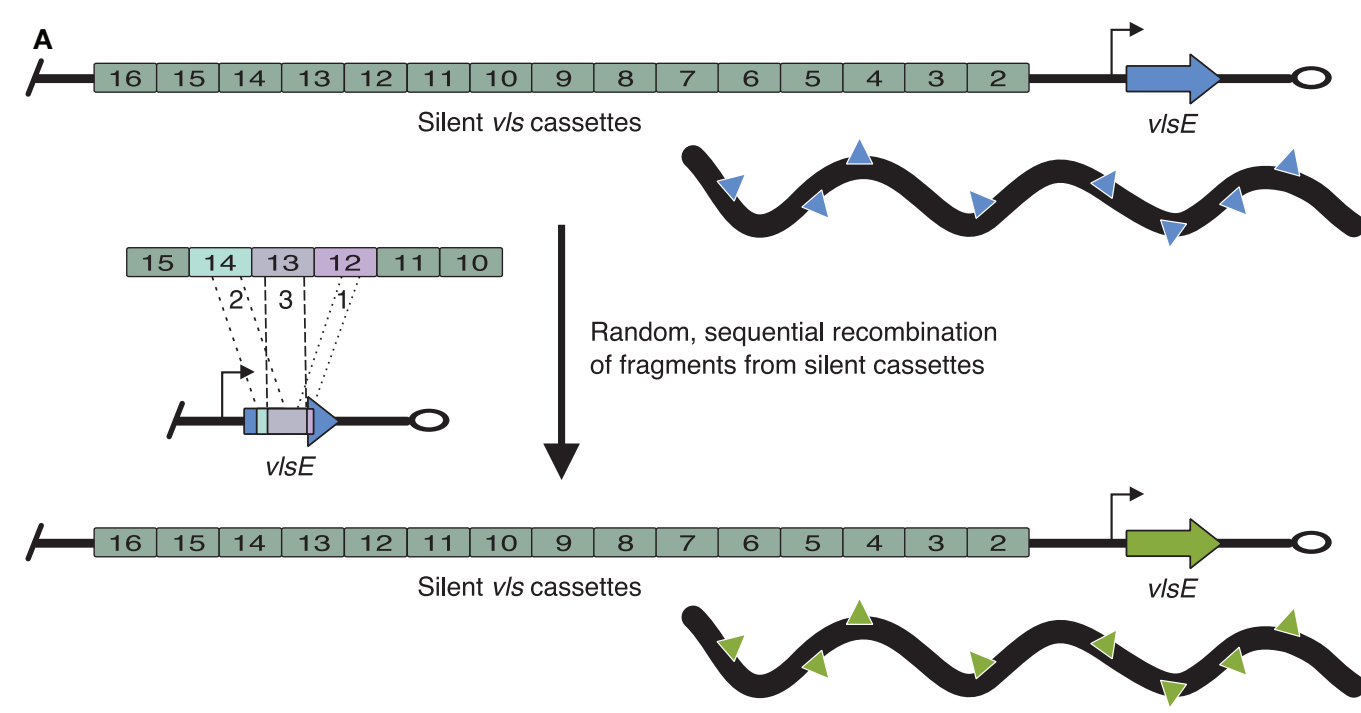

B
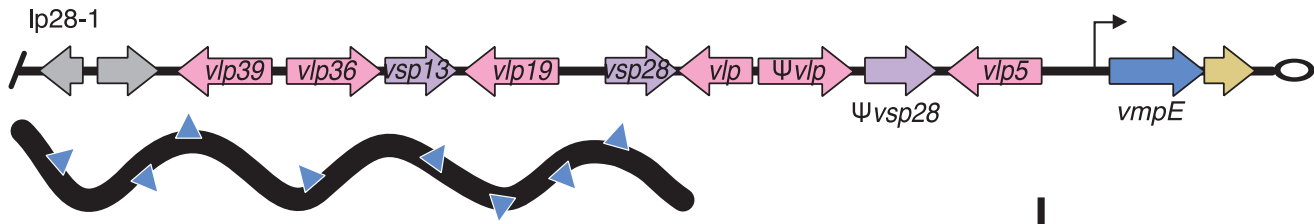

$\Psi_{\text {vsp28 }}$ $v m p E$

Recombination event

Deletion of active Vmp cassette

Insertion of a copy of new cassette from genome

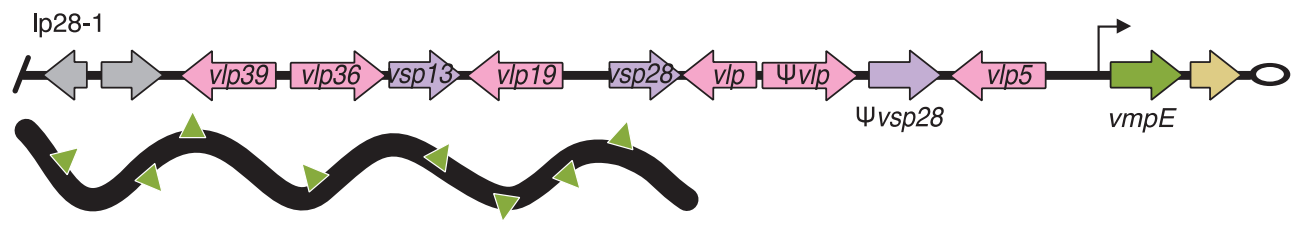

FIGURE 2 | Antigenic variation of Lyme borreliae VIsE and relapsing fever borreliae Vmp systems. (A) VIsE: the expression locus (VIsE) is located near the telomere (open oval) of linear plasmid (Ip) 28-1 (blue or green arrow, promoter is indicated by a black arrow). Silent v/s cassettes are located upstream and in the opposite orientation of v/sE. Antigenic variation occurs through the random and sequential insertion of silent cassette fragments (labeled 1, 2, and 3). (B) v/p (pink arrows) and vsp (purple arrows) cassettes are located throughout the genome on Ip28-1, 28-2, 28-3, 28-4, and 32-1. The expression locus (blue or green arrow, promoter is indicated by a black arrow) is found on Ip28-1 near the telomere (open oval). Changing the expressed Vmp cassette is achieved through deletion of the current cassette (blue arrow) followed by insertion of a copy of a new cassette (green arrow via recombination events) resulting in a change in the expressed $V m p$ on the surface of the bacterium (denoted by blue or green triangles, respectively). Gray arrows indicate non-Vmp ORFs; tan arrows indicate downstream homology sequences (DHS, sequences found throughout the genome and required for mapping recombination events at the Vmp expression locus). 
important in maintaining infection in mammals and helps Lyme Borrelia evade the humoral immune response (223-236). The Vls system is composed of approximately $16 v l s$ cassettes (the exact number varies by strain) and one expression locus, $v l s E$. All of the identified $v l s$ cassettes are located on the same plasmid (lp28-1) in close proximity to but in the opposite direction of $v l s E$. Expression at $v l s E$ occurs through the random recombination of segments of multiple $v l s$ cassettes rather than recombination of an entire, single $v l s$ cassette. Thus, recombination events result in thousands of unique VlsE variants, all approximately $36 \mathrm{kDa}$.

\section{Vmps of Relapsing Fever Borrelia}

Variable membrane proteins, a system similar to Vls, are one of the best characterized immune evasion mechanisms (199, 237-240). $B$. hermsii has approximately 60 unique and promoterless $v m p$ cassettes (i.e., silent cassettes) scattered throughout its genome and one promoter-driven $v m p$ expression locus (Figure 2). A single $v m p$ cassette is expressed when the entire cassette is moved to the expression locus.

The majority of spirochetes are cleared from the host through specific anti-Vmp IgM antibodies raised against the predominantly expressed Vmps, which results in a significant decrease in spirochete load (from approximately $10^{5}-10^{7}$ to $<10^{4} \mathrm{spi}$ rochetes $/ \mathrm{mL}$ ). The remaining spirochetes consist of a small population expressing different cassettes. Since the host has not raised a strong antibody response to these non-dominantly expressed Vmps, this minority population of spirochetes can proliferate to high concentrations until an antibody response is mounted and the majority of spirochetes are once again cleared. This cycle of $v m p$ conversion, peaking spirochete loads, and antibody-mediated clearing repeats a minimum of two times resulting in the characteristic symptoms of a relapsing fever illness.

\section{MECHANISMS OF IMMUNE EVASION BY B. miyamotoi: WHERE WE ARE}

Given the genetic similarity of $B$. miyamotoi to relapsing fever spirochetes, it is likely $B$. miyamotoi utilizes some homologous mechanisms to evade host immune responses. While B. miyamotoi is resistant to complement in vitro $(241,242)$, complement inactivation is not required for relapsing fever spirochetes to establish infection. OspE homologs have been identified in B. miyamotoi FR64b (isolated from the blood of $A$. argenteus); however, McDowell et al. were unable to demonstrate FH-binding (125). This suggests, as is the case for relapsing fever spirochetes, inactivation of complement may not be required to resolve spirochetemia during infection with B. miyamotoi $(115,243)$.

Instead, it appears B. miyamotoi utilizes a Vmp system (244), and Wagemakers et al. (100) recently demonstrated antigenic variation of Vmps in B. miyamotoi. $\mathrm{C} 3 \mathrm{H} / \mathrm{HeN}$ mice infected with B. miyamotoi LB-2001 produced anti-Vsp1 IgM and IgG antibodies that were effective in clearing the initial spirochetemic peak of B. miyamotoi from SCID mice. Despite this clearing, a second spirochetemic relapse occurred. Analyses of the secondary $B$. miyamotoi population revealed expression of $v l p C 2$, not $v s p 1$, as would be expected in the case of antigenic variation. They also noted $v l p C 2$ was present in the initial $B$. miyamotoi population in a much lower prevalence compared to $v s p 1$.

\section{MECHANISMS OF IMMUNE EVASION BY B. miyamotoi: WHERE WE NEED TO BE}

Even though $B$. miyamotoi is genetically similar to relapsing fever spirochetes, it has evolved and exists in different vectors (Ixodes not Ornithodoros) with different enzootic cycles and different co-pathogens compared to relapsing fever spirochetes. We should not assume B. miyamotoi utilizes the same set of mechanisms as other relapsing fever spirochetes. $B$. miyamotoi may use a combination of relapsing fever and Lyme Borrelia mechanisms as well as completely novel mechanisms.

The role of IgM in clearing B. miyamotoi has not been demonstrated. As discussed above, IgM is key in clearing relapsing fever infections. During $B$. hermsii infections, IgM targets FhbA and other surface proteins (113). IgM likely is important in clearing B. miyamotoi. All immunocompromised patients diagnosed with a B. miyamotoi infection developed meningoencephalitis. A shared factor with these patients has been treatment with rituximab, a monoclonal anti-CD20 antibody targeting IgM-producing CD20-positive B cells. Depletion of $\mathrm{B}$ cells may explain how B. miyamotoi is able to migrate to the CNS and causes meningoencephalitis in patients treated with rituximab. The presence of unknown complement inhibitors, however, could contribute to the complement resistance of $B$. miyamotoi and may be useful in establishing infection (241, 242).

The effects of tick saliva on $B$. miyamoto $i$ survival have not yet been studied. However, being vectored by Ixodes, B. miyamoto $i$ likely takes advantage of the protective proteins in tick saliva. In addition, understanding interactions between host, vector, and pathogen will aid in the development of Lyme and relapsing fever prevention strategies and thus requires more attention.

\section{CONCLUDING REMARKS}

Infection with B. miyamotoi in immunocompetent patients generally results in non-specific symptoms (e.g., headache, malaise), recurrent fever, and spirochetemia characteristic of relapsing fever. However, additional symptoms characteristic of relapsing fever have not been demonstrated, namely rapid symptom onset with a crisis event suggesting $B$. miyamoto infection is not synonymous with relapsing fever and is rather a relapsing fever-like illness (90). This should not be surprising given the different lifestyle of $B$. miyamotoi compared to the vast majority of relapsing fever spirochetes.

The ability to evade the immune response is important for any successful pathogen but many of the mechanisms B. miyamotoi 
utilizes remain undiscovered. Hindered by the lack of a robust animal model, the relatively long-standing inability to culture in vitro, and being unaware of its pathogenicity, our understanding of B. miyamotoi is still in its infancy. However, we are making large strides forward with recent advances in culture techniques, animals models, physicians actively considering B. miyamotoi infection, as well as a growing wealth of epidemiological data that will allow us to clarify the details of infection, genetics, and physiology of this emerging pathogen.

\section{REFERENCES}

1. Sparagano O, George D, Giangaspero A, Špitalská E. Arthropods and associated arthropod-borne diseases transmitted by migrating birds. The case of ticks and tick-borne pathogens. Vet Parasitol (2015) 213:61-6. doi:10.1016/ j.vetpar.2015.08.028

2. Diuk-Wasser MA, Vannier E, Krause PJ. Coinfection by Ixodes tick-borne pathogens: ecological, epidemiological, and clinical consequences. Trends Parasitol (2016) 32:30-42. doi:10.1016/j.pt.2015.09.008

3. Nelder MP, Russell CB, Sheehan NJ, Sander B, Moore S, Li Y, et al. Human pathogens associated with the blacklegged tick Ixodes scapularis: a systematic review. Parasit Vectors (2016) 9:265. doi:10.1186/s13071-016-1529-y

4. Richter D, Schlee DB, Allgöwer R, Matuschka F-R. Relationships of a novel Lyme disease spirochete, Borrelia spielmani sp. nov., with its hosts in central Europe. Appl Environ Microbiol (2004) 70:6414-9. doi:10.1128/ AEM.70.11.6414-6419.2004

5. Margos G, Vollmer SA, Cornet M, Garnier M, Fingerle V, Wilske B, et al. A new Borrelia species defined by multilocus sequence analysis of housekeeping genes. Appl Environ Microbiol (2009) 75:5410-6. doi:10.1128/ AEM.00116-09

6. Margos G, Vollmer SA, Ogden NH, Fish D. Population genetics, taxonomy, phylogeny and evolution of Borrelia burgdorferi sensu lato. Infect Genet Evol (2011) 11:1545-63. doi:10.1016/j.meegid.2011.07.022

7. Stanek G, Reiter M. The expanding Lyme Borrelia complex - clinical significance of genomic species? Clin Microbiol Infect (2011) 17:487-93. doi:10.1111/j.1469-0691.2011.03492.x

8. Rudenko N, Golovchenko M, Grubhoffer L, Oliver JH Jr. Updates on Borrelia burgdorferi sensu lato complex with respect to public health. Ticks Tick Borne Dis (2011) 2:123-8. doi:10.1016/j.ttbdis.2011.04.002

9. Ivanova LB, Tomova A, González-Acuña D, Murúa R, Moreno CX, Hernández C, et al. Borrelia chilensis, a new member of the Borrelia burgdorferi sensu lato complex that extends the range of this genospecies in the Southern Hemisphere. Environ Microbiol (2014) 16:1069-80. doi:10.1111/1462-2920.12310

10. Margos G, Piesman J, Lane RS, Ogden NH, Sing A, Straubinger RK, et al. Borrelia kurtenbachii sp. nov., a widely distributed member of the Borrelia burgdorferi sensu lato species complex in North America. Int J Syst Evol Microbiol (2014) 64:128-30. doi:10.1099/ijs.0.054593-0

11. Theiler A. Spirillosis of cattle. J Comp Pathol Ther (1904) 17:47-55. doi:10.1016/S0368-1742(04)80003-1

12. Barbour AG, Maupin GO, Teltow GJ, Carter CJ, Piesman J. Identification of an uncultivable Borrelia species in the hard tick Amblyomma americanum: possible agent of a Lyme disease-like illness. J Infect Dis (1996) 173:403-9. doi:10.1093/infdis/173.2.403

13. Takano A, Goka K, Une Y, Shimada Y, Fujita H, Shiino T, et al. Isolation and characterization of a novel Borrelia group of tick-borne borreliae from imported reptiles and their associated ticks. Environ Microbiol (2010) 12:134-46. doi:10.1111/j.1462-2920.2009.02054.x

14. Steere AC, Coburn J, Glickstein L. The emergence of Lyme disease. J Clin Invest (2004) 113:1093-101. doi:10.1172/JCI21681

15. Stanek G, Wormser GP, Gray J, Strle F. Lyme borreliosis. Lancet (2012) 379:461-73. doi:10.1016/S0140-6736(11)60103-7

16. Fukunaga M, Takahashi Y, Tsuruta Y, Matsushita O, Ralph D, McClelland M, et al. Genetic and phenotypic analysis of Borrelia miyamotoi sp. nov., isolated

\section{AUTHOR CONTRIBUTIONS}

All authors listed have made substantial, direct, and intellectual contribution to the work and approved it for publication.

\section{FUNDING}

This work was supported by NIH/NIAID grant 1R21AI26883-01 to $\mathrm{CAB}$.

from the ixodid tick Ixodes persulcatus, the vector for Lyme disease in Japan Int J Syst Bacteriol (1995) 45:804-10. doi:10.1099/00207713-45-4-804

17. Scoles GA, Papero M, Beati L, Fish D. A relapsing fever group spirochete transmitted by Ixodes scapularis ticks. Vector Borne Zoonotic Dis (2001) 1:21-34. doi:10.1089/153036601750137624

18. Fraenkel C-J, Garpmo U, Berglund J. Determination of novel Borrelia genospecies in Swedish Ixodes ricinus ticks. J Clin Microbiol (2002) 40:3308-12. doi:10.1128/JCM.40.9.3308-3312.2002

19. Richter D, Schlee DB, Matuschka F-R. Relapsing fever-like spirochetes infecting European vector tick of Lyme disease agent. Emerg Infect Dis (2003) 9:697-701. doi:10.3201/eid0906.020459

20. Ullmann AJ, Gabitzsch ES, Schulze TL, Zeidner NS, Piesman J. Three multiplex assays for detection of Borrelia burgdorferi sensu lato and Borrelia miyamotoi sensu lato in field-collected Ixodes nymphs in North America. J Med Entomol (2005) 42:1057-62. doi:10.1093/jmedent/42.6.1057

21. Mun J, Eisen RJ, Eisen L, Lane RS. Detection of a Borrelia miyamotoi sensu lato relapsing-fever group spirochete from Ixodes pacificus in California. J Med Entomol (2006) 43:120-3. doi:10.1093/jmedent/43.1.120

22. Richter D, Matuschka F-R. Modulatory effect of cattle on risk for Lyme disease. Emerg Infect Dis (2006) 12:1919. doi:10.3201/eid1212.051552

23. Hulínská D, Votỳpka J, Kř́iž B, Holínková N, Nováková J, Hulínskỳ V. Phenotypic and genotypic analysis of Borrelia spp. isolated from Ixodes ricinus ticks by using electrophoretic chips and real-time polymerase chain reaction. Folia Microbiol (Praha) (2007) 52:315-24. doi:10.1007/ BF02932085

24. Barbour AG, Bunikis J, Travinsky B, Hoen AG, Diuk-Wasser MA, Fish D, et al. Niche partitioning of Borrelia burgdorferi and Borrelia miyamotoi in the same tick vector and mammalian reservoir species. Am J Trop Med Hyg (2009) 81:1120-31. doi:10.4269/ajtmh.2009.09-0208

25. Hoen AG, Rollend LG, Papero MA, Carroll JF, Daniels TJ, Mather TN, et al. Effects of tick control by acaricide self-treatment of white-tailed deer on host-seeking tick infection prevalence and entomologic risk for Ixodes scapularis-borne pathogens. Vector Borne Zoonotic Dis (2009) 9:431-8. doi:10.1089/vbz.2008.0155

26. Wodecka B, Leonska A, Skotarczak B. A comparative analysis of molecular markers for the detection and identification of Borrelia spirochaetes in Ixodes ricinus. J Med Microbiol (2010) 59:309-14. doi:10.1099/jmm.0.013508-0

27. Tokarz R, Jain K, Bennett A, Briese T, Lipkin WI. Assessment of polymicrobial infections in ticks in New York State. Vector Borne Zoonotic Dis (2010) 10:217-21. doi:10.1089/vbz.2009.0036

28. Hamer SA, Tsao JI, Walker ED, Hickling GJ. Invasion of the Lyme disease vector Ixodes scapularis: implications for Borrelia burgdorferi endemicity. Ecohealth (2010) 7:47-63. doi:10.1007/s10393-010-0287-0

29. Scott MC, Rosen ME, Hamer SA, Baker E, Edwards H, Crowder C, et al. High-prevalence Borrelia miyamotoi infection among wild turkeys (Meleagris gallopavo) in Tennessee. J Med Entomol (2010) 47:1238-42. doi:10.1603/ ME10075

30. Wilhelmsson P, Fryland L, Borjesson S, Nordgren J, Bergstrom S, Ernerudh J, et al. Prevalence and diversity of Borrelia species in ticks that have bitten humans in Sweden. JClin Microbiol (2010) 48:4169-76. doi:10.1128/ JCM.01061-10

31. Richter D, Matuschka F-R. Elimination of Lyme disease spirochetes from ticks feeding on domestic ruminants. Appl Environ Microbiol (2010) 76:7650-2. doi:10.1128/AEM.01649-10 
32. Ogden NH, Margos G, Aanensen DM, Drebot MA, Feil EJ, Hanincova K, et al. Investigation of genotypes of Borrelia burgdorferi in Ixodes scapularis ticks collected during surveillance in Canada. Appl Environ Microbiol (2011) 77:3244-54. doi:10.1128/AEM.02636-10

33. Padgett KA, Bonilla DL. Novel exposure sites for nymphal Ixodes pacificus within picnic areas. Ticks Tick Borne Dis (2011) 2:191-5. doi:10.1016/j. ttbdis.2011.07.002

34. Richter D, Debski A, Hubalek Z, Matuschka F-R. Absence of Lyme disease spirochetes in larval Ixodes ricinus ticks. Vector Borne Zoonotic Dis (2012) 12:21-7. doi:10.1089/vbz.2011.0668

35. Hamer SA, Hickling GJ, Keith R, Sidge JL, Walker ED, Tsao JI. Associations of passerine birds, rabbits, and ticks with Borrelia miyamotoi and Borrelia andersonii in Michigan, U.S.A. Parasit Vectors (2012) 5:231. doi:10.1186/1756-3305-5-231

36. Rosen ME, Hamer SA, Gerhardt RR, Jones CJ, Muller LI, Scott MC, et al. Borrelia burgdorferi not detected in widespread Ixodes scapularis (Acari: Ixodidae) collected from white-tailed deer in Tennessee. J Med Entomol (2012) 49:1473-80. doi:10.1603/ME11255

37. Geller J, Nazarova L, Katargina O, Järvekülg L, Fomenko N, Golovljova I. Detection and genetic characterization of relapsing fever spirochete Borrelia miyamotoi in Estonian ticks. PLoS One (2012) 7:e51914. doi:10.1371/journal. pone.0051914

38. Subramanian G, Sekeyova Z, Raoult D, Mediannikov O. Multiple tick-associated bacteria in Ixodes ricinus from Slovakia. Ticks Tick Borne Dis (2012) 3:406-10. doi:10.1016/j.ttbdis.2012.10.001

39. Rollend L, Fish D, Childs JE. Transovarial transmission of Borrelia spirochetes by Ixodes scapularis: a summary of the literature and recent observations. Ticks Tick Borne Dis (2013) 4:46-51. doi:10.1016/j.ttbdis.2012.06.008

40. Taylor KR, Takano A, Konnai S, Shimozuru M, Kawabata H, Tsubota T. Borrelia miyamotoi infections among wild rodents show age and month independence and correlation with Ixodes persulcatus larval attachment in Hokkaido, Japan. Vector Borne Zoonotic Dis (2013) 13:92-7. doi:10.1089/ vbz.2012.1027

41. Wodecka B, Rymaszewska A, Skotarczak B. Host and pathogen DNA identification in blood meals of nymphal Ixodes ricinus ticks from forest parks and rural forests of Poland. Exp Appl Acarol (2013) 62:543-55. doi:10.1007/ s10493-013-9763-x

42. Salkeld DJ, Cinkovich S, Nieto NC. Tick-borne pathogens in northwestern California, USA. Emerg Infect Dis (2014) 20:493-4. doi:10.3201/ eid2003.130668

43. Michelet L, Delannoy S, Devillers E, Umhang G, Aspan A, Juremalm M, et al. High-throughput screening of tick-borne pathogens in Europe. Front Cell Infect Microbiol (2014) 4:103. doi:10.3389/fcimb.2014.00103

44. Mays SE, Hendricks BM, Paulsen DJ, Houston AE, Trout Fryxell RT. Prevalence of five tick-borne bacterial genera in adult Ixodes scapularis removed from white-tailed deer in western Tennessee. Parasit Vectors (2014) 7:473. doi:10.1186/s13071-014-0473-y

45. Padgett K, Bonilla D, Kjemtrup A, Vilcins I-M, Yoshimizu MH, Hui L, et al. Large scale spatial risk and comparative prevalence of Borrelia miyamotoi and Borrelia burgdorferi sensu lato in Ixodes pacificus. PLoS One (2014) 9:e110853. doi:10.1371/journal.pone.0110853

46. Cosson J-F, Michelet L, Chotte J, Naour EL, Cote M, Devillers E, et al. Genetic characterization of the human relapsing fever spirochete Borrelia miyamotoi in vectors and animal reservoirs of Lyme disease spirochetes in France. Parasit Vectors (2014) 7:233. doi:10.1186/1756-3305-7-233

47. Fonville M, Friesema IHM, Hengeveld PD, Docters van Leeuwen A, Jahfari S, Harms MG, et al. Human exposure to tickborne relapsing fever spirochete Borrelia miyamotoi, the Netherlands. Emerg Infect Dis (2014) 20:1244-5. doi:10.3201/eid2007.131525

48. Dibernardo A, Cote T, Ogden NH, Lindsay LR. The prevalence of Borrelia miyamotoi infection, and co-infections with other Borrelia spp. in Ixodes scapularis ticks collected in Canada. Parasit Vectors (2014) 7:183. doi:10.1186/1756-3305-7-183

49. Eshoo MW, Crowder CD, Carolan HE, Rounds MA, Ecker DJ, Haag H, et al. Broad-range survey of tick-borne pathogens in Southern Germany reveals a high prevalence of Babesia microti and a diversity of other tickborne pathogens. Vector Borne Zoonotic Dis (2014) 14:584-91. doi:10.1089/ vbz.2013.1498
50. Burri C, Schumann O, Schumann C, Gern L. Are Apodemus spp. mice and Myodes glareolus reservoirs for Borrelia miyamotoi, Candidatus Neoehrlichia mikurensis, Rickettsia helvetica, R. monacensis and Anaplasma phagocytophilum? Ticks Tick Borne Dis (2014) 5:245-51. doi:10.1016/j.ttbdis.2013. 11.007

51. Mukhacheva TA, Kovalev SY. Borrelia spirochetes in Russia: genospecies differentiation by real-time PCR. Ticks Tick Borne Dis (2014) 5:722-6. doi:10.1016/j.ttbdis.2014.05.016

52. Takano A, Toyomane K, Konnai S, Ohashi K, Nakao M, Ito T, et al. Tick surveillance for relapsing fever spirochete Borrelia miyamotoi in Hokkaido, Japan. PLoS ONE (2014) 9:e104532. doi:10.1371/journal.pone.0104532

53. Crowder CD, Carolan HE, Rounds MA, Honig V, Mothes B, Haag H, et al. Prevalence of Borrelia miyamotoi in Ixodes ticks in Europe and the United States. Emerg Infect Dis (2014) 20:1678-82. doi:10.3201/eid2010.131583

54. Hamer SA, Hickling GJ, Walker ED, Tsao JI. Increased diversity of zoonotic pathogens and Borrelia burgdorferi strains in established versus incipient Ixodes scapularis populations across the Midwestern United States. Infect Genet Evol (2014) 27:531-42. doi:10.1016/j.meegid.2014.06.003

55. Kiewra D, Stańczak J, Richter M. Ixodes ricinus ticks (Acari, Ixodidae) as a vector of Borrelia burgdorferi sensu lato and Borrelia miyamotoi in Lower Silesia, Poland - preliminary study. Ticks Tick Borne Dis (2014) 5:892-7. doi:10.1016/j.ttbdis.2014.07.004

56. Fedorova N, Kleinjan JE, James D, Hui LT, Peeters H, Lane RS. Remarkable diversity of tick or mammalian-associated Borreliae in the metropolitan San Francisco Bay Area, California. Ticks Tick Borne Dis (2014) 5:951-61. doi:10.1016/j.ttbdis.2014.07.015

57. Lommano E, Dvořák C, Vallotton L, Jenni L, Gern L. Tick-borne pathogens in ticks collected from breeding and migratory birds in Switzerland. Ticks Tick Borne Dis (2014) 5:871-82. doi:10.1016/j.ttbdis.2014.07.001

58. Schreiber C, Krücken J, Beck S, Maaz D, Pachnicke S, Krieger K, et al. Pathogens in ticks collected from dogs in Berlin/Brandenburg, Germany. Parasit Vectors (2014) 7:535. doi:10.1186/s13071-014-0535-1

59. Mukhacheva TA, Salikhova II, Kovalev SY. Multilocus spacer analysis revealed highly homogeneous genetic background of Asian type of Borrelia miyamotoi. Infect Genet Evol (2015) 31:257-62. doi:10.1016/j.meegid.2015. 02.009

60. Reiter M, Schötta A-M, Müller A, Stockinger H, Stanek G. A newly established real-time PCR for detection of Borrelia miyamotoi in Ixodes ricinus ticks. Ticks Tick Borne Dis (2015) 6(3):303-8. doi:10.1016/j.ttbdis.2015.02.002

61. Hansford KM, Fonville M, Jahfari S, Sprong H, Medlock JM. Borrelia miyamotoi in host-seeking Ixodes ricinus ticks in England. Epidemiol Infect (2015) 143:1079-87. doi:10.1017/S0950268814001691

62. Cochez C, Heyman P, Heylen D, Fonville M, Hengeveld P, Takken W, et al. The presence of Borrelia miyamotoi, a relapsing fever spirochaete, in questing Ixodes ricinus in Belgium and in the Netherlands. Zoonoses Public Health (2015) 62:331-3. doi:10.1111/zph.12154

63. Eshoo MW, Carolan HE, Massire C, Chou DM, Crowder CD, Rounds MA, et al. Survey of Ixodes pacificus ticks in California reveals a diversity of microorganisms and a novel and widespread Anaplasmataceae species. PLoS One (2015) 10:e0135828. doi:10.1371/journal.pone.0135828

64. Salkeld DJ, Nieto NC, Carbajales-Dale P, Carbajales-Dale M, Cinkovich SS, Lambin EF. Disease risk \& landscape attributes of tick-borne Borrelia pathogens in the San Francisco Bay Area, California. PLoS One (2015) 10:e0134812. doi:10.1371/journal.pone.0134812

65. Szekeres S, Coipan EC, Rigó K, Majoros G, Jahfari S, Sprong H, et al. Ecoepidemiology of Borrelia miyamotoi and Lyme borreliosis spirochetes in a popular hunting and recreational forest area in Hungary. Parasit Vectors (2015) 8:309. doi:10.1186/s13071-015-0922-2

66. Quarsten H, Skarpaas T, Fajs L, Noraas S, Kjelland V. Tick-borne bacteria in Ixodes ricinus collected in southern Norway evaluated by a commercial kit and established real-time PCR protocols. Ticks Tick Borne Dis (2015) 6:538-44. doi:10.1016/j.ttbdis.2015.04.008

67. Kjelland V, Rollum R, Korslund L, Slettan A, Tveitnes D. Borrelia miyamotoi is widespread in Ixodes ricinus ticks in southern Norway. Ticks Tick Borne Dis (2015) 6:516-21. doi:10.1016/j.ttbdis.2015.04.004

68. Nunes M, Parreira R, Lopes N, Maia C, Carreira T, Sousa C, et al. Molecular identification of Borrelia miyamotoi in Ixodes ricinus from Portugal. Vector Borne Zoonotic Dis (2015) 15:515-7. doi:10.1089/vbz.2014.1765 
69. Cerar T, Korva M, Avšič-Županc T, Ružić-Sabljić E. Detection, identification and genotyping of Borrellia spp. in rodents in Slovenia by PCR and culture. BMC Vet Res (2015) 11:188. doi:10.1186/s12917-015-0501-y

70. Edwards MJ, Barbalato LA, Makkapati A, Pham KD, Bugbee LM. Relatively low prevalence of Babesia microti and Anaplasma phagocytophilum in Ixodes scapularis ticks collected in the Lehigh Valley region of eastern Pennsylvania. Ticks Tick Borne Dis (2015) 6:812-9. doi:10.1016/j.ttbdis.2015.07.009

71. Sytykiewicz H, Karbowiak G, Chorostowska-Wynimko J, Szpechciński A, Supergan-Marwicz M, Horbowicz M, et al. Coexistence of Borrelia burgdorferi s.l. genospecies within Ixodes ricinus ticks from central and eastern Poland. Acta Parasitol (2015) 60:654-61. doi:10.1515/ap-2015-0093

72. Wodecka B, Skotarczak B. Identification of host blood-meal sources and Borrelia in field-collected Ixodes ricinus ticks in north-western Poland. Ann Agric Environ Med (2016) 23:59-63. doi:10.5604/12321966.1196853

73. Sormunen JJ, Klemola T, Vesterinen EJ, Vuorinen I, Hytönen J, Hänninen J, et al. Assessing the abundance, seasonal questing activity, and Borrelia and tick-borne encephalitis virus (TBEV) prevalence of Ixodes ricinus ticks in a Lyme borreliosis endemic area in Southwest Finland. Ticks Tick Borne Dis (2016) 7:208-15. doi:10.1016/j.ttbdis.2015.10.011

74. Han S, Hickling GJ, Tsao JI. High prevalence of Borrelia miyamotoi among adult blacklegged ticks from white-tailed deer. Emerg Infect Dis (2016) 22:316-8. doi:10.3201/eid2202.151218

75. Tadin A, Tokarz R, Markotić A, Margaletić J, Turk N, Habuš J, et al. Molecular survey of zoonotic agents in rodents and other small mammals in Croatia. Am J Trop Med Hyg (2016) 94:466-73. doi:10.4269/ajtmh.15-0517

76. van Duijvendijk G, Coipan C, Wagemakers A, Fonville M, Ersöz J, Oei A, et al. Larvae of Ixodes ricinus transmit Borrelia afzelii and B. miyamotoi to vertebrate hosts. Parasit Vectors (2016) 9:97. doi:10.1186/s13071-016-1389-5

77. Khasnatinov MA, Danchinova GA, Takano A, Kawabata H, Ohashi N, Masuzawa T. Prevalence of Borrelia miyamotoi in Ixodes persulcatus in Irkutsk city and its neighboring territories, Russia. Ticks Tick Borne Dis (2016) 7:394-7. doi:10.1016/j.ttbdis.2015.12.016

78. Heylen D, Fonville M, van Leeuwen AD, Sprong H. Co-infections and transmission dynamics in a tick-borne bacterium community exposed to songbirds. Environ Microbiol (2016) 18:988-96. doi:10.1111/1462-2920.13164

79. Kalmár Z, Sprong H, Mihalca AD, Gherman CM, Dumitrache MO, Coipan EC, et al. Borrelia miyamotoi and Candidatus Neoehrlichia mikurensis in Ixodes ricinus Ticks, Romania. Emerg Infect Dis (2016) 22:550-1. doi:10.3201/ eid2203.150140

80. Sormunen JJ, Penttinen R, Klemola T, Hänninen J, Vuorinen I, Laaksonen M, et al. Tick-borne bacterial pathogens in southwestern Finland. Parasit Vectors (2016) 9:168. doi:10.1186/s13071-016-1449-x

81. Paul REL, Cote M, Le Naour E, Bonnet SI. Environmental factors influencing tick densities over seven years in a French suburban forest. Parasit Vectors (2016) 9:309. doi:10.1186/s13071-016-1591-5

82. Skotarczak B, Wodecka B, Rymaszewska A, Adamska M. Molecular evidence for bacterial pathogens in Ixodes ricinus ticks infesting Shetland ponies. Exp Appl Acarol (2016) 69:179-89. doi:10.1007/s10493-016-0027-4

83. Wodecka B, Michalik J, Lane RS, Nowak-Chmura M, Wierzbicka A. Differential associations of Borrelia species with European badgers (Meles meles) and raccoon dogs (Nyctereutes procyonoides) in western Poland. Ticks Tick Borne Dis (2016) 7:1010-6. doi:10.1016/j.ttbdis.2016.05.008

84. Potkonjak A, Kleinerman G, Gutiérrez R, Savić S, Vračar V, Nachum-Biala Y, et al. Occurrence of Borrelia burgdorferi sensu lato in Ixodes ricinus ticks with first identification of Borrelia miyamotoi in Vojvodina, Serbia. Vector Borne Zoonotic Dis (2016) 16(10):631-5. doi:10.1089/vbz.2016.2008

85. Platonov AE, Karan LS, Kolyasnikova NM, Makhneva NA, Toporkova MG, Maleev VV, et al. Humans Infected with relapsing fever spirochete Borrelia miyamotoi, Russia. Emerg Infect Dis (2011) 17:1816-23. doi:10.3201/ eid1710.101474

86. Chowdri HR, Gugliotta JL, Berardi VP, Goethert HK, Molloy PJ, Sterling SL, et al. Borrelia miyamotoi infection presenting as human granulocytic anaplasmosis: a case report. Ann Intern Med (2013) 159:21-7. doi:10.7326/0003-4819-159-1-201307020-00005

87. Hovius JWR, de Wever B, Sohne M, Brouwer MC, Coumou J, Wagemakers A, et al. A case of meningoencephalitis by the relapsing fever spirochaete Borrelia miyamotoi in Europe. Lancet (2013) 382:658. doi:10.1016/ S0140-6736(13)61644-X
88. Gugliotta JL, Goethert HK, Berardi VP, Telford SR III. Meningoencephalitis from Borrelia miyamotoi in an immunocompromised patient. $N$ Engl J Med (2013) 368:240-5. doi:10.1056/NEJMoa1209039

89. Sato K, Takano A, Konnai S, Nakao M, Ito T, Koyama K, et al. Human infections with Borrelia miyamotoi, Japan. Emerg Infect Dis (2014) 20:1391-4. doi:10.3201/eid2008.131761

90. Telford SR III, Goethert HK, Molloy PJ, Berardi VP, Chowdri HR, Gugliotta $\mathrm{JL}$, et al. Borrelia miyamotoi disease: neither Lyme disease nor relapsing fever. Clin Lab Med (2015) 35(4):867-82. doi:10.1016/j.cll.2015.08.002

91. Molloy PJ, Telford SR, Chowdri HR, Lepore TJ, Gugliotta JL, Weeks KE, et al. Borrelia miyamotoi disease in the Northeastern United States: a case series. Ann Intern Med (2015) 163:91-8. doi:10.7326/M15-0333

92. Sudhindra P, Wang G, Schriefer ME, McKenna D, Zhuge J, Krause PJ, et al. Insights into Borrelia miyamotoi infection from an untreated case demonstrating relapsing fever, monocytosis and a positive C6 Lyme serology. Diagn Microbiol Infect Dis (2016) 86:93-6. doi:10.1016/j.diagmicrobio.2016. 06.015

93. Magnarelli LA, Anderson JF, Johnson RC. Cross-reactivity in serological tests for Lyme disease and other spirochetal infections. J Infect Dis (1987) 156:183-8. doi:10.1093/infdis/156.1.183

94. Lee S, Vigliotti J, Vigliotti V, Jones W, Shearer D. Detection of borreliae in archived sera from patients with clinically suspect Lyme disease. Int $J \mathrm{Mol} S \mathrm{Si}$ (2014) 15:4284-98. doi:10.3390/ijms15034284

95. Margolis N, Hogan D, Cieplak W, Schwan TG, Rosa PA. Homology between Borrelia burgdorferi OspC and members of the family of Borrelia hermsit variable major proteins. Gene (1994) 143:105-10. doi:10.1016/0378-1119(94) 90613-0

96. Cutler SJ, Moss J, Fukunaga M, Wright DJ, Fekade D, Warrell D. Borrelia recurrentis characterization and comparison with relapsing-fever, Lymeassociated, and other Borrelia spp. Int J Syst Bacteriol (1997) 47:958-68. doi:10.1099/00207713-47-4-958

97. Stevenson B, Porcella SF, Oie KL, Fitzpatrick CA, Raffel SJ, Lubke L, et al. The relapsing fever spirochete Borrelia hermsii contains multiple, antigen-encoding circular plasmids that are homologous to the cp32 plasmids of Lyme disease spirochetes. Infect Immun (2000) 68:3900-8. doi:10.1128/ IAI.68.7.3900-3908.2000

98. Di L, Pagan PE, Packer D, Martin CL, Akther S, Ramrattan G, et al. BorreliaBase: a phylogeny-centered browser of Borrelia genomes. BMC Bioinformatics (2014) 15:233. doi:10.1186/1471-2105-15-233

99. Krause PJ, Hendrickson JE, Steeves TK, Fish D. Blood transfusion transmission of the tick-borne relapsing fever spirochete Borrelia miyamotoi in mice. Transfusion (2015) 55:593-7. doi:10.1111/trf.12879

100. Wagemakers A, Koetsveld J, Narasimhan S, Wickel M, Deponte K, Bleijlevens B, et al. Variable major proteins as targets for specific antibodies against Borrelia miyamotoi. J Immunol (2016) 196:4185-95. doi:10.4049/ jimmunol.1600014

101. Barthold SW, Beck DS, Hansen GM, Terwilliger GA, Moody KD. Lyme borreliosis in selected strains and ages of laboratory mice. J Infect Dis (1990) 162:133-8. doi:10.1093/infdis/162.1.133

102. Barthold SW, de Souza MS, Janotka JL, Smith AL, Persing DH. Chronic Lyme borreliosis in the laboratory mouse. Am J Pathol (1993) 143:959-71.

103. Cadavid D. The mammalian host response to Borrelia infection. Wien Klin Wochenschr (2006) 118:653-8. doi:10.1007/s00508-006-0692-0

104. Krause PJ, Narasimhan S, Wormser GP, Rollend L, Fikrig E, Lepore T, et al. Human Borrelia miyamotoi infection in the United States. N Engl J Med (2013) 368:291-3. doi:10.1056/NEJMc1215469

105. Krause PJ, Narasimhan S, Wormser GP, Barbour AG, Platonov AE, Brancato $\mathrm{J}$, et al. Borrelia miyamotoi sensu lato seroreactivity and seroprevalence in the Northeastern United States. Emerg Infect Dis (2014) 20:1183-90. doi:10.3201/ eid2007.131587

106. Hu LT, Tsibris AM, Branda JA. Case 24-2015: a 28-year-old pregnant woman with fever, chills, headache, and fatigue. N Engl J Med (2015) 373:468-75. doi:10.1056/NEJMcpc1501763

107. Sarksyan DS, Platonov AE, Karan LS, Shipulin GA, Sprong H, Hovius JWR. Probability of spirochete Borrelia miyamotoi transmission from ticks to humans. Emerg Infect Dis (2015) 21:2273-4. doi:10.3201/eid2112.151097

108. Cerar T, Strle F, Stupica D, Ruzic-Sabljic E, McHugh G, Steere AC, et al. Differences in genotype, clinical features, and inflammatory potential of 
Borrelia burgdorferi sensu stricto strains from Europe and the United States. Emerg Infect Dis (2016) 22:818-27. doi:10.3201/eid2205.151806

109. Bunikis J, Tsao J, Garpmo U, Berglund J, Fish D, Barbour AG. Typing of Borrelia relapsing fever group strains. Emerg Infect Dis (2004) 10:1661. doi:10.3201/eid1009.040236

110. Fihn S, Larson EB. Tick-borne relapsing fever in the Pacific Northwest: an underdiagnosed illness? West J Med (1980) 133:203-9.

111. Boden K, Lobenstein S, Hermann B, Margos G, Fingerle V. Borrelia miyamotoi-associated neuroborreliosis in immunocompromised person. Emerg Infect Dis (2016) 22:1617-20. doi:10.3201/eid2209.152034

112. Merle NS, Church SE, Fremeaux-Bacchi V, Roumenina LT. Complement system part I - molecular mechanisms of activation and regulation. Front Immunol (2015) 6:262. doi:10.3389/fimmu.2015.00262

113. Colombo MJ, Alugupalli KR. Complement factor H-binding protein, a putative virulence determinant of Borrelia hermsii, is an antigenic target for protective B1b lymphocytes. J Immunol (2008) 180:4858-64. doi:10.4049/ jimmunol.180.7.4858

114. Belperron AA, Dailey CM, Bockenstedt LK. Infection-induced marginal zone B cell production of Borrelia hermsii-specific antibody is impaired in the absence of CD1d. JImmunol (2005) 174:5681-6. doi:10.4049/ jimmunol.174.9.5681

115. Connolly SE, Benach JL. Cutting edge: the spirochetemia of murine relapsing fever is cleared by complement-independent bactericidal antibodies. J Immunol (2001) 167:3029-32. doi:10.4049/jimmunol.167.6.3029

116. Alugupalli KR, Leong JM, Woodland RT, Muramatsu M, Honjo T, Gerstein RM. B1b lymphocytes confer T cell-independent long-lasting immunity. Immunity (2004) 21:379-90. doi:10.1016/j.immuni.2004.06.019

117. Alugupalli KR, Gerstein RM, Chen J, Szomolanyi-Tsuda E, Woodland RT, Leong JM. The resolution of relapsing fever borreliosis requires IgM and is concurrent with expansion of B1b lymphocytes. JImmunol (2003) 170:3819-27. doi:10.4049/jimmunol.170.7.3819

118. Barbour AG, Bundoc V. In vitro and in vivo neutralization of the relapsing fever agent Borrelia hermsii with serotype-specific immunoglobulin $\mathrm{M}$ antibodies. Infect Immun (2001) 69:1009-15. doi:10.1128/IAI.69.2.1009-1015.2001

119. Dickinson GS, Piccone H, Sun G, Lien E, Gatto L, Alugupalli KR. Toll-like receptor 2 deficiency results in impaired antibody responses and septic shock during Borrelia hermsii infection. Infect Immun (2010) 78:4579-88. doi:10.1128/IAI.00438-10

120. Vuyyuru R, Liu H, Manser T, Alugupalli KR. Characteristics of Borrelia hermsii infection in human hematopoietic stem cell-engrafted mice mirror those of human relapsing fever. Proc Natl Acad Sci U S A (2011) 108:20707-12. doi:10.1073/pnas.1108776109

121. Dickinson GS, Sun G, Bram RJ, Alugupalli KR. Efficient B cell responses to Borrelia hermsii infection depend on BAFF and BAFFR but not TACI. Infect Immun (2014) 82:453-9. doi:10.1128/IAI.01147-13

122. Noris M, Remuzzi G. Overview of complement activation and regulation. Semin Nephrol (2013) 33:479-92. doi:10.1016/j.semnephrol.2013.08.001

123. Ricklin D, Reis ES, Lambris JD. Complement in disease: a defence system turning offensive. Nat Rev Nephrol (2016) 12:383-401. doi:10.1038/ nrneph.2016.70

124. Kraiczy P. Hide and seek: how Lyme disease spirochetes overcome complement attack. Front Immunol (2016) 7:385. doi:10.3389/fimmu.2016.00385

125. McDowell JV, Wolfgang J, Tran E, Metts MS, Hamilton D, Marconi RT. Comprehensive analysis of the factor $\mathrm{H}$ binding capabilities of Borrelia species associated with Lyme disease: delineation of two distinct classes of factor H binding proteins. Infect Immun (2003) 71:3597-602. doi:10.1128/ IAI.71.6.3597-3602.2003

126. Kraiczy P, Skerka C, Kirschfink M, Zipfel PF, Brade V. Immune evasion of Borrelia burgdorferi: insufficient killing of the pathogens by complement and antibody. Int J Med Microbiol (2002) 291(Suppl 33):141-6. doi:10.1016/ S1438-4221(02)80027-3

127. Brade V, Kleber I, Acker G. Differences of two Borrelia burgdorferi strains in complement activation and serum resistance. Immunobiology (1992) 185:453-65. doi:10.1016/S0171-2985(11)80087-2

128. Breitner-Ruddock S, Würzner R, Schulze J, Brade V. Heterogeneity in the complement-dependent bacteriolysis within the species of Borrelia burgdorferi. Med Microbiol Immunol (1997) 185:253-60. doi:10.1007/s00430 0050038
129. Kraiczy P, Hunfeld K-P, Breitner-Ruddock S, Würzner R, Acker G, Brade V. Comparison of two laboratory methods for the determination of serum resistance in Borrelia burgdorferi isolates. Immunobiology (2000) 201:406-19. doi:10.1016/S0171-2985(00)80094-7

130. Van Dam AP, Oei A, Jaspars R, Fijen C, Wilske B, Spanjaard L, et al. Complement-mediated serum sensitivity among spirochetes that cause Lyme disease. Infect Immun (1997) 65:1228-36.

131. Kurtenbach K, De Michelis S, Etti S, Schäfer SM, Sewell H-S, Brade V, et al. Host association of Borrelia burgdorferi sensu lato - the key role of host complement. Trends Microbiol (2002) 10:74-9. doi:10.1016/S0966-842X(01) 02298-3

132. Friese MA, Hellwage J, Jokiranta TS, Meri S, Peter HH, Eibel H, et al. FHL-1/reconectin and factor $\mathrm{H}$ : two human complement regulators which are encoded by the same gene are differently expressed and regulated. Mol Immunol (1999) 36:809-18. doi:10.1016/S0161-5890(99)00101-7

133. Gordon DL, Kaufman RM, Blackmore TK, Kwong J, Lublin DM. Identification of complement regulatory domains in human factor H. J Immunol (1995) 155:348-56.

134. Kühn S, Skerka C, Zipfel PF. Mapping of the complement regulatory domains in the human factor H-like protein 1 and in factor H. JImmunol (1995) 155:5663-70.

135. Oppermann M, Manuelian T, Józsi M, Brandt E, Jokiranta TS, Heinen S, et al. The C-terminus of complement regulator factor $\mathrm{H}$ mediates target recognition: evidence for a compact conformation of the native protein. Clin Exp Immunol (2006) 144:342-52. doi:10.1111/j.1365-2249.2006.03071.x

136. Pangburn MK, Atkinson MA, Meri S. Localization of the heparin-binding site on complement factor H. J Biol Chem (1991) 266:16847-53.

137. Blackmore TK, Hellwage J, Sadlon TA, Higgs N, Zipfel PF, Ward HM, et al. Identification of the second heparin-binding domain in human complement factor H. J Immunol (1998) 160:3342-8.

138. Blackmore TK, Sadlon TA, Ward HM, Lublin DM, Gordon DL. Identification of a heparin binding domain in the seventh short consensus repeat of complement factor H. J Immunol (1996) 157:5422-7.

139. Meri S, Pangburn MK. Discrimination between activators and nonactivators of the alternative pathway of complement: regulation via a sialic acid/polyanion binding site on factor H. Proc Natl Acad Sci U S A (1990) 87:3982-6. doi:10.1073/pnas.87.10.3982

140. Meri S, Pangburn MK. Regulation of alternative pathway complement activation by glycosaminoglycans: specificity of the polyanion binding site on factor H. Biochem Biophys Res Commun (1994) 198:52-9. doi:10.1006/ bbrc. 1994.1008

141. Kouser L, Abdul-Aziz M, Nayak A, Stover CMM, Sim RBP, Kishore UP. Properdin and factor $\mathrm{H}$ : opposing players on the alternative complement pathway "see-saw". Front Immunol (2013) 4:93. doi:10.3389/fimmu.2013. 00093

142. Ferreira VP, Pangburn MK, Cortés C. Complement control protein factor H: the good, the bad, and the inadequate. Mol Immunol (2010) 47:2187-97. doi:10.1016/j.molimm.2010.05.007

143. Alitalo A, Meri T, Rämö L, Jokiranta TS, Heikkilä T, Seppälä IJT, et al. Complement evasion by Borrelia burgdorferi: serum-resistant strains promote C3b inactivation. Infect Immun (2001) 69:3685-91. doi:10.1128/ IAI.69.6.3685-3691.2001

144. Kraiczy P, Stevenson B. Complement regulator-acquiring surface proteins of Borrelia burgdorferi: structure, function and regulation of gene expression. Ticks Tick Borne Dis (2013) 4:26-34. doi:10.1016/j.ttbdis.2012.10.039

145. Pulzova L, Bhide M. Outer surface proteins of Borrelia: peerless immune evasion tools. Curr Protein Pept Sci (2014) 15:75-88. doi:10.2174/1389203 715666140221124213

146. Meri T, Cutler SJ, Blom AM, Meri S, Jokiranta TS. Relapsing fever spirochetes Borrelia recurrentis and $B$. duttonii acquire complement regulators C4bbinding protein and factor H. Infect Immun (2006) 74:4157-63. doi:10.1128/ IAI.00007-06

147. Bhide MR, Escudero R, Camafeita E, Gil H, Jado I, Anda P. Complement factor $\mathrm{H}$ binding by different Lyme disease and relapsing fever Borrelia in animals and human. BMC Res Notes (2009) 2:134. doi:10.1186/17560500-2-134

148. Grosskinsky S, Schott M, Brenner C, Cutler SJ, Simon MM, Wallich R. Human complement regulators $\mathrm{C} 4 \mathrm{~b}$-binding protein and $\mathrm{C} 1$ esterase 
inhibitor interact with a novel outer surface protein of Borrelia recurrentis. PLoS Negl Trop Dis (2010) 4:e698. doi:10.1371/journal.pntd.0000698

149. Brenner C, Bomans K, Habicht J, Simon MM, Wallich R. Mapping the ligand-binding region of Borrelia hermsii fibronectin-binding protein. PLoS One (2013) 8:e63437. doi:10.1371/journal.pone.0063437

150. Schwab J, Hammerschmidt C, Richter D, Skerka C, Matuschka F-R, Wallich $\mathrm{R}$, et al. Borrelia valaisiana resist complement-mediated killing independently of the recruitment of immune regulators and inactivation of complement components. PLoS One (2013) 8:e53659. doi:10.1371/journal.pone. 0053659

151. Lewis ERG, Marcsisin RA, Miller SAC, Hue F, Phillips A, AuCoin DP, et al. Fibronectin-binding protein of Borrelia hermsii expressed in the blood of mice with relapsing fever. Infect Immun (2014) 82:2520-31. doi:10.1128/ IAI.01582-14

152. Hovis KM, McDowell JV, Griffin L, Marconi RT. Identification and characterization of a linear-plasmid-encoded factor H-binding protein (FhbA) of the relapsing fever spirochete Borrelia hermsii. J Bacteriol (2004) 186:2612-8. doi:10.1128/JB.186.9.2612-2618.2004

153. Rossmann E, Kraiczy P, Herzberger P, Skerka C, Kirschfink M, Simon MM, et al. Dual binding specificity of a Borrelia hermsii-associated complement regulator-acquiring surface protein for factor $\mathrm{H}$ and plasminogen discloses a putative virulence factor of relapsing fever spirochetes. J Immunol (2007) 178:7292-301. doi:10.4049/jimmunol.178.11.7292

154. Woodman ME, Cooley AE, Avdiushko R, Bowman A, Botto M, Wooten RM, et al. Roles for phagocytic cells and complement in controlling relapsing fever infection. J Leukoc Biol (2009) 86:727-36. doi:10.1189/jlb.0309169

155. Fine LM, Miller DP, Mallory KL, Tegels BK, Earnhart CG, Marconi RT. The Borrelia hermsii factor $\mathrm{H}$ binding protein FhbA is not required for infectivity in mice or for resistance to human complement in vitro. Infect Immun (2014) 82:3324-32. doi:10.1128/IAI.01892-14

156. Ermert D, Blom AM. C4b-binding protein: the good, the bad and the deadly. Novel functions of an old friend. Immunol Lett (2016) 169:82-92. doi:10.1016/j.imlet.2015.11.014

157. Pietikäinen J, Meri T, Blom AM, Meri S. Binding of the complement inhibitor C4b-binding protein to Lyme disease borreliae. Mol Immunol (2010) 47:1299-305. doi:10.1016/j.molimm.2009.11.028

158. Sandholm K, Henningsson AJ, Säve S, Bergström S, Forsberg P, Jonsson N, et al. Early cytokine release in response to live Borrelia burgdorferi sensu lato spirochetes is largely complement independent. PLoS One (2014) 9:e108013. doi:10.1371/journal.pone. 0108013

159. Madar M, Bencurova E, Mlynarcik P, Almeida AM, Soares R, Bhide K, et al. Exploitation of complement regulatory proteins by Borrelia and Francisella. Mol Biosyst (2015) 11:1684-95. doi:10.1039/C5MB00027K

160. Hammerschmidt C, Klevenhaus Y, Koenigs A, Hallström T, Fingerle V, Skerka C, et al. BGA66 and BGA71 facilitate complement resistance of Borrelia bavariensis by inhibiting assembly of the membrane attack complex. Mol Microbiol (2016) 99:407-24. doi:10.1111/mmi.13239

161. van Dam AP, Kuiper H, Vos K, Widjojokusumo A, de Jongh BM, Spanjaard L, et al. Different genospecies of Borrelia burgdorferi are associated with distinct clinical manifestations of Lyme borreliosis. Clin Infect Dis (1993) 17:708-17. doi:10.1093/clinids/17.4.708

162. Alitalo A, Meri T, Comstedt P, Jeffery L, Tornberg J, Strandin T, et al. Expression of complement factor $\mathrm{H}$ binding immunoevasion proteins in Borrelia garinii isolated from patients with neuroborreliosis. Eur J Immunol (2005) 35:3043-53. doi:10.1002/eji.200526354

163. Hodzic E, Feng S, Barthold SW. Assessment of transcriptional activity of Borrelia burgdorferi and host cytokine genes during early and late infection in a mouse model. Vector Borne Zoonotic Dis (2013) 13:694-711. doi:10.1089/ vbz.2012.1189

164. Pausa M, Pellis V, Cinco M, Giulianini PG, Presani G, Perticarari S, et al. Serum-resistant strains of Borrelia burgdorferi evade complement-mediated killing by expressing a CD59-like complement inhibitory molecule. J Immunol (2003) 170:3214-22. doi:10.4049/jimmunol.170.6.3214

165. Ribeiro JM, Weis JJ, Telford SR. Saliva of the tick Ixodes dammini inhibits neutrophil function. Exp Parasitol (1990) 70:382-8. doi:10.1016/0014-4894(90)90121-R

166. Ribeiro JMC, Alarcon-Chaidez FB, Francischetti IM, Mans BJ, Mather TN, Valenzuela JG, et al. An annotated catalog of salivary gland transcripts from Ixodes scapularis ticks. Insect Biochem Mol Biol (2006) 36:111-29. doi:10.1016/j.ibmb.2005.11.005

167. Lewis LA, Radulović ŽM, Kim TK, Porter LM, Mulenga A. Identification of $24 \mathrm{~h}$ Ixodes scapularis immunogenic tick saliva proteins. Ticks Tick Borne Dis (2015) 6:424-34. doi:10.1016/j.ttbdis.2015.03.012

168. Kim TK, Tirloni L, Pinto AFM, Moresco J, Yates JR III, da Silva Vaz I Jr, et al. Ixodes scapularis tick saliva proteins sequentially secreted every $24 \mathrm{~h}$ during blood feeding. PLoS Negl Trop Dis (2016) 10:e0004323. doi:10.1371/journal. pntd. 0004323

169. Nuttall PA, Labuda M. Tick-host interactions: saliva-activated transmission. Parasitology (2004) 129:S177-89. doi:10.1017/S0031182004005633

170. Narasimhan S, DePonte K, Marcantonio N, Liang X, Royce TE, Nelson KF, et al. Immunity against Ixodes scapularis salivary proteins expressed within 24 hours of attachment thwarts tick feeding and impairs Borrelia transmission. PLoS One (2007) 2:e451. doi:10.1371/journal.pone.0000451

171. Zeidner NS, Schneider BS, Nuncio MS, Gern L, Piesman J. Coinoculation of Borrelia spp. with tick salivary gland lysate enhances spirochete load in mice and is tick species-specific. J Parasitol (2002) 88:1276-8. doi:10.1645/0022-3395(2002)088[1276:COBSWT]2.0.CO;2

172. Ramamoorthi N, Narasimhan S, Pal U, Bao F, Yang XF, Fish D, et al. The Lyme disease agent exploits a tick protein to infect the mammalian host. Nature (2005) 436:573-7. doi:10.1038/nature03812

173. Kuthejlová M, Kopecký J, Stepánová G, Macela A. Tick salivary gland extract inhibits killing of Borrelia afzelii spirochetes by mouse macrophages. Infect Immun (2001) 69:575-8. doi:10.1128/IAI.69.1.575-578.2001

174. Severinová J, Salát J, Kročová Z, Rezníčková J, Demová H, Horká H, et al. Co-inoculation of Borrelia afzelii with tick salivary gland extract influences distribution of immunocompetent cells in the skin and lymph nodes of mice. Folia Microbiol (Praha) (2005) 50:457-63. doi:10.1007/BF02931430

175. Guo X, Booth CJ, Paley MA, Wang X, DePonte K, Fikrig E, et al. Inhibition of neutrophil function by two tick salivary proteins. Infect Immun (2009) 77:2320-9. doi:10.1128/IAI.01507-08

176. Horká H, Cerná-Kýcková K, Skallová A, Kopecký J. Tick saliva affects both proliferation and distribution of Borrelia burgdorferi spirochetes in mouse organs and increases transmission of spirochetes to ticks. Int J Med Microbiol (2009) 299:373-80. doi:10.1016/j.ijmm.2008.10.009

177. Marchal C, Schramm F, Kern A, Luft BJ, Yang X, Schuijt T, et al. Antialarmin effect of tick saliva during the transmission of Lyme disease. Infect Immun (2011) 79:774-85. doi:10.1128/IAI.00482-10

178. Lawrie CH, Randolph SE, Nuttall PA. Ixodes ticks: serum species sensitivity of anticomplement activity. Exp Parasitol (1999) 93:207-14. doi:10.1006/ expr.1999.4456

179. Gillespie RD, Mbow ML, Titus RG. The immunomodulatory factors of bloodfeeding arthropod saliva. Parasite Immunol (2000) 22:319-31. doi:10.1046/j.1365-3024.2000.00309.x

180. Valenzuela JG, Charlab R, Mather TN, Ribeiro JMC. Purification, cloning, and expression of a novel salivary anticomplement protein from the tick, Ixodes scapularis. J Biol Chem (2000) 275:18717-23. doi:10.1074/jbc. M001486200

181. Lawrie CH, Sim RB, Nuttall PA. Investigation of the mechanisms of anti-complement activity in Ixodes ricinus ticks. Mol Immunol (2005) 42:31-8. doi:10.1016/j.molimm.2004.07.001

182. Daix V, Schroeder H, Praet N, Georgin J-P, Chiappino I, Gillet L, et al. Ixodes ticks belonging to the Ixodes ricinus complex encode a family of anticomplement proteins. Insect Mol Biol (2007) 16:155-66. doi:10.1111/j.1365-2583.2006.00710.x

183. Hourcade DE, Akk AM, Mitchell LM, Zhou H, Hauhart R, Pham CTN. Anti-complement activity of the Ixodes scapularis salivary protein Salp20. Mol Immunol (2016) 69:62-9. doi:10.1016/j.molimm.2015.11.008

184. Hovius JWR, de Jong MAWP, den Dunnen J, Litjens M, Fikrig E, van der Poll T, et al. Salp15 binding to DC-SIGN inhibits cytokine expression by impairing both nucleosome remodeling and mRNA stabilization. PLoS Pathog (2008) 4:e31. doi:10.1371/journal.ppat.0040031

185. Anguita J, Ramamoorthi N, Hovius JWR, Das S, Thomas V, Persinski R, et al. Salp15, an Ixodes scapularis salivary protein, inhibits CD4+ T cell activation. Immunity (2002) 16:849-59. doi:10.1016/S1074-7613(02)00325-4

186. Hovius JW, Schuijt TJ, de Groot KA, Roelofs JJTH, Oei GA, Marquart JA, et al. Preferential protection of Borrelia burgdorferi sensu stricto by a Salp 
15 homologue in Ixodes ricinus saliva. J Infect Dis (2008) 198:1189-97. doi: $10.1086 / 591917$

187. Schuijt TJ, Hovius JWR, van Burgel ND, Ramamoorthi N, Fikrig E, van Dam AP. The tick salivary protein Salp15 inhibits the killing of serum-sensitive Borrelia burgdorferi sensu lato isolates. Infect Immun (2008) 76:2888-94. doi:10.1128/IAI.00232-08

188. Murase Y, Konnai S, Yamada S, Githaka N, Isezaki M, Ito T, et al. An investigation of binding ability of Ixodes persulcatus Schulze Salp15 with Lyme disease spirochetes. Insect Biochem Mol Biol (2015) 60:59-67. doi:10.1016/ j.ibmb.2015.01.010

189. Dai J, Wang P, Adusumilli S, Booth CJ, Narasimhan S, Anguita J, et al. Antibodies against a tick protein, Salp15, protect mice from the Lyme disease agent. Cell Host Microbe (2009) 6:482-92. doi:10.1016/j.chom.2009.10.006

190. Tyson K, Elkins C, Patterson H, Fikrig E, De Silva A. Biochemical and functional characterization of Salp20, an Ixodes scapularis tick salivary protein that inhibits the complement pathway. Insect Mol Biol (2007) 16:469-79. doi:10.1111/j.1365-2583.2007.00742.x

191. Tyson KR, Elkins C, de Silva AM. A novel mechanism of complement inhibition unmasked by a tick salivary protein that binds to properdin. J Immunol (2008) 180:3964-8. doi:10.4049/jimmunol.180.6.3964

192. Couvreur B, Beaufays J, Charon C, Lahaye K, Gensale F, Denis V, et al. Variability and action mechanism of a family of anticomplement proteins in Ixodes ricinus. PLoS One (2008) 3:e1400. doi:10.1371/journal.pone.0001400

193. Astigarraga A, Oleaga-Pérez A, Pérez-Sánchez R, Baranda JA, EncinasGrandes A. Host immune response evasion strategies in Ornithodoros erraticus and O. moubata and their relationship to the development of an antiargasid vaccine. Parasite Immunol (1997) 19:401-10. doi:10.104 6/j.1365-3024.1997.d01-236.x

194. Tabuchi N, Kataoka-Ushijima Y, Talbert A, Mitani H, Fukunaga M. Absence of transovarial transmission of Borrelia duttonii, a tick-borne relapsing fever agent, by the vector tick Ornithodoros moubata. Vector Borne Zoonotic Dis (2008) 8:607-13. doi:10.1089/vbz.2007.0279

195. Nunn MA, Sharma A, Paesen GC, Adamson S, Lissina O, Willis AC, et al. Complement inhibitor of C5 activation from the soft tick Ornithodoros moubata. J Immunol (2005) 174:2084-91. doi:10.4049/jimmunol.174.4.2084

196. Hepburn NJ, Williams AS, Nunn MA, Chamberlain-Banoub JC, Hamer $\mathrm{J}$, Morgan BP, et al. In vivo characterization and therapeutic efficacy of a C5-specific inhibitor from the soft tick Ornithodoros moubata. J Biol Chem (2007) 282:8292-9. doi:10.1074/jbc.M609858200

197. Ma Y, Weis JJ. Borrelia burgdorferi outer surface lipoproteins OspA and OspB possess B-cell mitogenic and cytokine-stimulatory properties. Infect Immun (1993) 61:3843-53.

198. Bolz DD, Sundsbak RS, Ma Y, Akira S, Kirschning CJ, Zachary JF, et al. MyD88 plays a unique role in host defense but not arthritis development in Lyme disease. J Immunol (2004) 173:2003-10. doi:10.4049/jimmunol.173.3.2003

199. Meier JT, Simon MI, Barbour AG. Antigenic variation is associated with DNA rearrangements in a relapsing fever Borrelia. Cell (1985) 41:403-9. doi:10.1016/S0092-8674(85)80013-1

200. Barbour AG, Burman N, Carter CJ, Kitten T, Bergström S. Variable antigen genes of the relapsing fever agent Borrelia hermsii are activated by promoter addition. Mol Microbiol (1991) 5:489-93. doi:10.1111/j.1365-2958.1991. tb02132.x

201. Marconi RT, Samuels DS, Schwan TG, Garon CF. Identification of a protein in several Borrelia species which is related to OspC of the Lyme disease spirochetes. J Clin Microbiol (1993) 31:2577-83.

202. Carter CJ, Bergström S, Norris SJ, Barbour AG. A family of surface-exposed proteins of 20 kilodaltons in the genus Borrelia. Infect Immun (1994) 62:2792-9.

203. Zhang J-R, Hardham JM, Barbour AG, Norris SJ. Antigenic variation in Lyme disease borreliae by promiscuous recombination of Vmp-like sequence cassettes. Cell (1997) 89:275-85. doi:10.1016/S0092-8674(00)80206-8

204. Burman N, Shamaei-Tousi A, Bergström S. The spirochete Borrelia crocidurae causes erythrocyte rosetting during relapsing fever. Infect Immun (1998) 66:815-9.

205. Brissette CA, Cooley AE, Burns LH, Riley SP, Verma A, Woodman ME, et al. Lyme borreliosis spirochete Erp proteins, their known host ligands, and potential roles in mammalian infection. Int J Med Microbiol (2008) 298:257-67. doi:10.1016/j.jimm.2007.09.004
206. Kenedy MR, Lenhart TR, Akins DR. The role of Borrelia burgdorferi outer surface proteins. FEMS Immunol Med Microbiol (2012) 66:1-19. doi:10.1111/j.1574-695X.2012.00980.x

207. Schutzer SE, Coyle PK, Krupp LB, Deng Z, Belman AL, Dattwyler R, et al. Simultaneous expression of Borrelia OspA and OspC and IgM response in cerebrospinal fluid in early neurologic Lyme disease. JClin Invest (1997) 100:763-7. doi:10.1172/JCI119589

208. Bunikis J, Barbour AG. Access of antibody or trypsin to an integral outer membrane protein (P66) of Borrelia burgdorferi is hindered by Osp lipoproteins. Infect Immun (1999) 67:2874-83.

209. Schwan TG, Piesman J, Golde WT, Dolan MC, Rosa PA. Induction of an outer surface protein on Borrelia burgdorferi during tick feeding. Proc Natl Acad Sci U S A (1995) 92:2909-13. doi:10.1073/pnas.92.7.2909

210. Liang FT, Jacobs MB, Bowers LC, Philipp MT. An immune evasion mechanism for spirochetal persistence in Lyme borreliosis. J Exp Med (2002) 195:415-22. doi:10.1084/jem.20011870

211. Grimm D, Tilly K, Byram R, Stewart PE, Krum JG, Bueschel DM, et al. Outer-surface protein $\mathrm{C}$ of the Lyme disease spirochete: a protein induced in ticks for infection of mammals. Proc Natl Acad Sci U S A (2004) 101:3142-7. doi:10.1073/pnas.0306845101

212. Pal U, Yang X, Chen M, Bockenstedt LK, Anderson JF, Flavell RA, et al. OspC facilitates Borrelia burgdorferi invasion of Ixodes scapularis salivary glands. J Clin Invest (2004) 113:220-30. doi:10.1172/JCI19894

213. Lagal V, Portnoï D, Faure G, Postic D, Baranton G. Borrelia burgdorferi sensu stricto invasiveness is correlated with OspC-plasminogen affinity. Microbes Infect (2006) 8:645-52. doi:10.1016/j.micinf.2005.08.017

214. Tilly K, Krum JG, Bestor A, Jewett MW, Grimm D, Bueschel D, et al. Borrelia burgdorferi OspC protein required exclusively in a crucial early stage of mammalian infection. Infect Immun (2006) 74:3554-64. doi:10.1128/IAI. 01950-05

215. Tilly K, Bestor A, Jewett MW, Rosa P. Rapid clearance of Lyme disease spirochetes lacking OspC from skin. Infect Immun (2007) 75:1517-9. doi:10.1128/ IAI.01725-06

216. Carrasco SE, Troxell B, Yang Y, Brandt SL, Li H, Sandusky GE, et al. Outer surface protein $\mathrm{OspC}$ is an antiphagocytic factor that protects Borrelia burgdorferi from phagocytosis by macrophages. Infect Immun (2015) 83:4848-60. doi:10.1128/IAI.01215-15

217. Theisen M, Borre M, Mathiesen MJ, Mikkelsen B, Lebech A-M, Hansen K. Evolution of the Borrelia burgdorferi outer surface protein OspC. J Bacteriol (1995) 177:3036-44. doi:10.1128/jb.177.11.3036-3044.1995

218. Seinost G, Dykhuizen DE, Dattwyler RJ, Golde WT, Dunn JJ, Wang I-N, et al. Four clones of Borrelia burgdorferi sensu stricto cause invasive infection in humans. Infect Immun (1999) 67:3518-24.

219. Wang I-N, Dykhuizen DE, Qiu W, Dunn JJ, Bosler EM, Luft BJ. Genetic diversity of ospC in a local population of Borrelia burgdorferi sensu stricto. Genetics (1999) 151:15-30.

220. Brisson D, Dykhuizen DE. ospC diversity in Borrelia burgdorferi different hosts are different niches. Genetics (2004) 168:713-22. doi:10.1534/ genetics.104.028738

221. Earnhart CG, Buckles EL, Dumler JS, Marconi RT. Demonstration of OspC type diversity in invasive human Lyme disease isolates and identification of previously uncharacterized epitopes that define the specificity of the OspC murine antibody response. Infect Immun (2005) 73:7869-77. doi:10.1128/ IAI.73.12.7869-7877.2005

222. Wormser GP, Brisson D, Liveris D, Hanincová K, Sandigursky S, Nowakowski $\mathrm{J}$, et al. Borrelia burgdorferi genotype predicts the capacity for hematogenous dissemination during early Lyme disease. J Infect Dis (2008) 198:1358-64. doi: $10.1086 / 592279$

223. Lawrenz MB, Hardham JM, Owens RT, Nowakowski J, Steere AC, Wormser GP, et al. Human antibody responses to VlsE antigenic variation protein of Borrelia burgdorferi. J Clin Microbiol (1999) 37:3997-4004.

224. Hudson CR, Frye JG, Quinn FD, Gherardini FC. Increased expression of Borrelia burgdorferi $v l s E$ in response to human endothelial cell membranes. Mol Microbiol (2001) 41:229-39. doi:10.1046/j.1365-2958.2001.02511.x

225. Anguita J, Thomas V, Samanta S, Persinski R, Hernanz C, Barthold SW, et al. Borrelia burgdorferi-induced inflammation facilitates spirochete adaptation and variable major protein-like sequence locus recombination. J Immunol (2001) 167:3383-90. doi:10.4049/jimmunol.167.6.3383 
226. Crother TR, Champion CI, Wu X-Y, Blanco DR, Miller JN, Lovett MA. Antigenic composition of Borrelia burgdorferi during infection of SCID mice. Infect Immun (2003) 71:3419-28. doi:10.1128/IAI.71.6.3419-3428.2003

227. Piesman J, Zeidner NS, Schneider BS. Dynamic changes in Borrelia burgdorferi populations in Ixodes scapularis (Acari: Ixodidae) during transmission: studies at the mRNA level. Vector Borne Zoonotic Dis (2003) 3:125-32. doi:10.1089/153036603768395825

228. Liang FT, Yan J, Mbow ML, Sviat SL, Gilmore RD, Mamula M, et al. Borrelia burgdorferi changes its surface antigenic expression in response to host immune responses. Infect Immun (2004) 72:5759-67. doi:10.1128/ IAI.72.10.5759-5767.2004

229. Lawrenz MB, Wooten RM, Norris SJ. Effects of $v l s E$ complementation on the infectivity of Borrelia burgdorferi lacking the linear plasmid lp28-1. Infect Immun (2004) 72:6577-85. doi:10.1128/IAI.72.11.6577-6585.2004

230. Bankhead T, Chaconas G. The role of VlsE antigenic variation in the Lyme disease spirochete: persistence through a mechanism that differs from other pathogens. Mol Microbiol (2007) 65:1547-58. doi:10.1111/j.1365-2958.2007.05895.x

231. Coutte L, Botkin DJ, Gao L, Norris SJ. Detailed analysis of sequence changes occurring during $v l s E$ antigenic variation in the mouse model of Borrelia burgdorferi infection. PLoS Pathog (2009) 5:e1000293. doi:10.1371/journal. ppat.1000293

232. Baum E, Hue F, Barbour AG. Experimental infections of the reservoir species Peromyscus leucopus with diverse strains of Borrelia burgdorferi, a Lyme disease agent. MBio (2012) 3:e434-412. doi:10.1128/mBio.00434-12

233. Rogovskyy AS, Bankhead T. Variable VlsE is critical for host reinfection by the Lyme disease spirochete. PLoS One (2013) 8:e61226. doi:10.1371/journal. pone.0061226

234. Tilly K, Bestor A, Rosa PA. Lipoprotein succession in Borrelia burgdorferi: similar but distinct roles for OspC and VlsE at different stages of mammalian infection. Mol Microbiol (2013) 89:216-27. doi:10.1111/mmi.12271

235. Norris SJ. $v l s$ antigenic variation systems of Lyme disease Borrelia: eluding host immunity through both random, segmental gene conversion and framework heterogeneity. Microbiol Spectr (2014) (6):1-18. doi:10.1128/ microbiolspec.MDNA3-0038-2014

236. Jacek E, Tang KS, Komorowski L, Ajamian M, Probst C, Stevenson B, et al. Epitope-specific evolution of human B cell responses to Borrelia burgdorferi VlsE protein from early to late stages of Lyme disease. J Immunol (2016) 196:1036-43. doi:10.4049/jimmunol.1501861
237. Barbour AG. Antigenic variation of a relapsing fever Borrelia species. Annu Rev Microbiol (1990) 44:155-71. doi:10.1146/annurev.mi.44.100190. 001103

238. Barbour AG, Carter CJ, Sohaskey CD. Surface protein variation by expression site switching in the relapsing fever agent Borrelia hermsii. Infect Immun (2000) 68:7114-21. doi:10.1128/IAI.68.12.7114-7121.2000

239. Barbour AG, Dai Q, Restrepo BI, Stoenner HG, Frank SA. Pathogen escape from host immunity by a genome program for antigenic variation. Proc Natl Acad Sci U S A (2006) 103:18290-5. doi:10.1073/pnas.0605302103

240. Dai Q, Restrepo BI, Porcella SF, Raffel SJ, Schwan TG, Barbour AG. Antigenic variation by Borrelia hermsii occurs through recombination between extragenic repetitive elements on linear plasmids. Mol Microbiol (2006) 60:1329-43. doi:10.1111/j.1365-2958.2006.05177.x

241. Teegler A, Herzberger P, Margos G, Fingerle V, Kraiczy P. The relapsing fever spirochete Borrelia miyamotoi resists complement-mediated killing by human serum. Ticks Tick Borne Dis (2014) 5:898-901. doi:10.1016/ j.ttbdis.2014.07.011

242. Wagemakers A, Oei A, Fikrig MM, Miellet WR, Hovius JW. The relapsing fever spirochete Borrelia miyamotoi is cultivable in a modified KellyPettenkofer medium, and is resistant to human complement. Parasit Vectors (2014) 7:418. doi:10.1186/1756-3305-7-418

243. Newman K, Johnson RC. In vivo evidence that an intact lytic complement pathway is not essential for successful removal of circulating Borrelia turicatae from mouse blood. Infect Immun (1981) 31:465-9.

244. Hamase A, Takahashi Y, Nohgi K, Fukunaga M. Homology of variable major protein genes between Borrelia hermsii and Borrelia miyamotoi. FEMS Microbiol Lett (1996) 140:131-7. doi:10.1111/j.1574-6968.1996. tb08326.x

Conflict of Interest Statement: The authors declare that the research was conducted in the absence of any commercial or financial relationships that could be construed as a potential conflict of interest.

Copyright (C) 2017 Stone and Brissette. This is an open-access article distributed under the terms of the Creative Commons Attribution License (CC BY). The use, distribution or reproduction in other forums is permitted, provided the original author $(s)$ or licensor are credited and that the original publication in this journal is cited, in accordance with accepted academic practice. No use, distribution or reproduction is permitted which does not comply with these terms. 